Rubber agroforests and governance at the interface between conservation and livelihoods in Bungo district, Jambi province, Indonesia

Endri Martini, Ratna Akiefnawati, Laxman Joshi, Sonya Dewi, Andree Ekadinata, Laurène Feintrenie, Meine van Noordwijk 



\section{Rubber agroforests and governance at the interface between conservation and livelihoods in Bungo district, Jambi province, Indonesia}

Endri Martini, Ratna Akiefnawati, Laxman Joshi, Sonya Dewi, Andree Ekadinata, Laurène Feintrenie, Meine van Noordwijk 


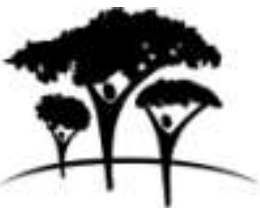

World Agroforestry Centre

TRANSFORMING LIVES AND LANDSCAPES

\section{Correct citation}

Martini E, Akiefnawati R, Joshi L, Dewi S, Ekadinata A, Feintrenie L, van Noordwijk M. 2010. Rubber agroforests and governance at the interface between conservation and livelihoods in Bungo district, Jambi province, Indonesia. Working paper 124. Bogor, Indonesia: World Agroforestry Centre. 53p

Titles in the Working Paper series disseminate interim results on agroforestry research and practices to stimulate feedback from the scientific community. Other publication series from the World Agroforestry Centre include agroforestry perspectives, technical manuals and occasional papers.

Published by the World Agroforestry Centre (ICRAF)

Southeast Asia Regional Program

PO Box 161, Bogor 16001

Indonesia

Tel: +622518625415

Fax: +62 2518625416

Email: icraf-indonesia@cgiar.org

Website: http:// www.worldagroforestry.org/sea

(C) World Agroforestry Centre 2010

Working Paper 124

The views expressed in this publication are those of the author(s) and not necessarily those of the World Agroforestry Centre. Articles appearing in this publication may be quoted or reproduced without charge, provided the source is acknowledged. All images remain the sole property of their source and may not be used for any purpose without written permission of the source. 


\section{About the authors}

Endri Martini is a forester with research interest in multistakeholder perspectives and negotiation, balancing the tradeoffs between biodiversity conservation with livelihood enhancement. She joined the World Agroforestry Centre in 2002. In the Landscape Mosaic project, from 2007 to 2009, she was involved in analysing governance of natural resources in Bungo district, Jambi, Indonesia. Since 2009, funded by HICDUSAID, she is pursuing her master's program at the Department of Natural Resources and Environmental Management at the University of Hawaii, Manoa, USA.

Ratna Akiefnawati joined the Centre in 1996 as Site Coordinator in Muara Bungo, Jambi, Indonesia. She completed her Master in Agriculture from Brawijaya University, Malang, East Java in 1995. She was involved in Alternative to Slash and Burn research, Belowground Biodiversity Project, Rewarding Up-land Poor for Environmental Services project, Smallholder Rubber Agroforestry System research and local knowledge study as well as land-use surveys. She is also active in the multi-stakeholder discussion forum and forest governance learning group in Bungo district as Coordinator and Facilitator.

Laxman Joshi received his PhD in Agroforestry from University of Wales, Bangor, UK, in 1998 and has over 20 years of professional experience in the field of forestry and agroforestry for smallholder farmers in South and Southeast Asia. During his 12 years at the World Agroforestry Centre in Indonesia his research focus was on local ecological knowledge and smallholder rubber agroforestry systems in Jambi and West Kalimantan. He also lead research projects on green infrastructure in post-tsunami Aceh. He recently moved to the International Centre for Integrated Mountain Development in Kathmandu to work in the area of rewards for environmental services.

Sonya Dewi is a Landscape Ecologist with formal backgrounds in soil science, computer science and theoretical ecology. She has worked extensively on broad tropical landscape issues from assessment of livelihoods and environmental services through identification of opportunities and constraints on sustainable livelihoods and multifunctional landscapes to studies of spatial land-use planning principles and practices. She also explores possible mechanisms of rewards for environmental services, including climate change mitigation through REDD+.

Andree Ekadinata is a Remote Sensing Specialist, primarily focused on image processing and spatial analysis for natural resource management, including biodiversity assessments. He has extensive experiences in interpreting imagery in Southeast Asia, Africa and Latin America, as well as across broad application and research questions within natural resource management areas, such as climate change mitigation, watershed management and spatial land-use planning.

Laurène Feintrenie received her $\mathrm{PhD}$ in Human Geography in 2010 from the University of Montpellier III, France, after a Master degree in Agronomy Sciences, specialised in tropical areas (IRC, Montpellier, France). She has been working with the Center for International Forestry Research, Bogor, Indonesia, since 2007, as a visiting scientist and consultant. Her PhD dealt with landscape dynamics in Bungo district, with a focus on the conversion of rubber agroforests into monoculture plantations of rubber and oil palm.

Meine van Noordwijk is an ecologist who joined the Centre's Southeast Asia Program in Bogor in 1993 to support the activities of the Alternatives to Slash and Burn Program, now the ASB Partnership for the Tropical Forest Margins. He served as regional coordinator from 2002-2009 and is now the Centre's Chief Science Advisor. He obtained his PhD in 1987 from Wageningen Agricultural University in the Netherlands. 


\begin{abstract}
Multiple forces are at work in most landscapes. The area in Jambi province, Indonesia, that was selected as one of the benchmark sites for the global study of biodiversity in mixed landscapes is no exception. The history of land use and the key local and external stakeholders associated with change form the backdrop for the dynamics studied. Major changes in the Bungo district of Jambi province started with Dutch colonial expansion in 1906 and the associated introduction of Hevea brasiliensis ('para' rubber) linked to trade networks at the mouth of the Batanghari River, the major transport route. The 1970s started another period of rapid change with roads, commercial logging and transmigration projects, followed by oil palm expansion. The current stakeholders, at landscape and local levels, reflect this history in their perceptions and ambitions. Formal governance processes in Indonesia as a whole have started to have a direct influence on local dynamics, including management of natural resources, rule enforcement and conflict resolution. The current links between various levels of governance (from local to national) influence the ways conflicts can be resolved and solutions negotiated. The interface between conservation and livelihoods in Bungo is still dominated by rubber agroforests that date back almost a century, but these may become an anachronism, a remnant of the past in a world where the conservation versus livelihood trade-off lost its intermediate ('land sharing') solutions to multi-functionality.
\end{abstract}

\title{
Keywords
}

rubber agroforest, conservation, livelihood, governance, Bungo 


\section{Acknowledgements}

This study was funded by Swiss Agency for Development and Cooperative through the Centre for International Forestry Research and the World Agroforestry Centre's biodiversity platform, 'Research on biodiversity conservation on a landscape level', as part of the project, Integrating livelihoods and multiple biodiversity values in Landscape Mosaics. The authors appreciate the assistance and contribution of the collaborating communities and local government offices in Bungo district. The authors also would like to acknowledge the hard work of Robert Finlayson who has patiently edited the manuscript, and Katarina Riswandi and the Centre's publication team for book design and production. 


\section{Contents}

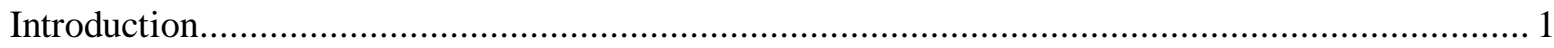

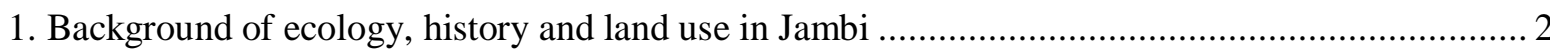

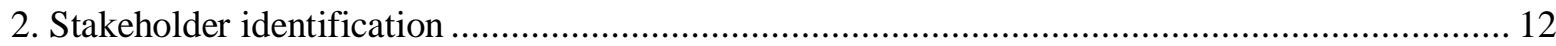

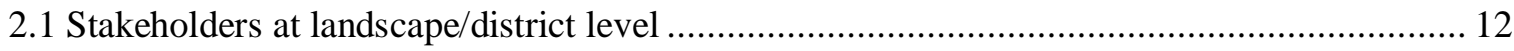

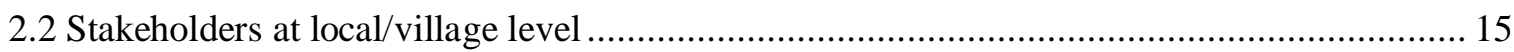

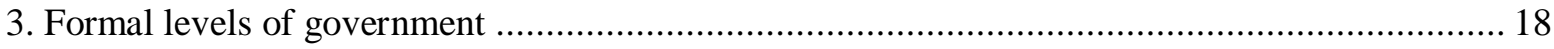

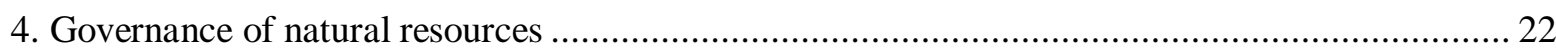

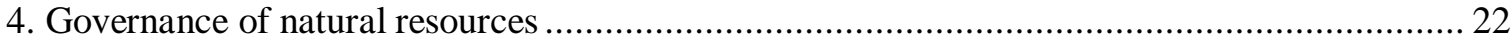

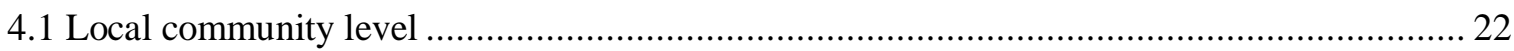

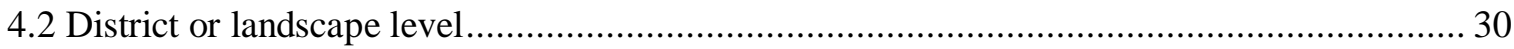

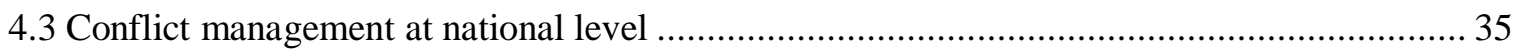

5. Links between governing bodies at local and district level ................................................. 37

5.1 Issues, conflicts and collaboration between the two levels of governance ............................. 37

5.2 Communication patterns and trust between the two levels ................................................... 40

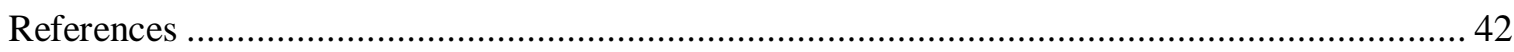

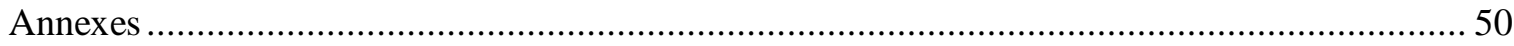




\section{Introduction}

A landscape mosaic (diverse land use in a landscape) is shaped by decision makers operating from local to national levels. Concerns over biodiversity and greenhouse gas emissions have recently added international players to the list of stakeholders.

This study describes and analyses the multiple forces at work on a landscape in Jambi province, Indonesia, that was selected as one of the benchmarks for the global study of biodiversity in landscape mosaics.

We begin with a brief background of the landscape, the history of land use and the key stakeholders associated with change. Section 2 provides more details about the various stakeholders, at landscape and local levels, including their perceptions and ambitions. Section 3 describes formal governance processes in Indonesia. Section 4 discusses specific issues of governance that relate to the management of natural resources, rule enforcement and conflict resolution. Section 5 focuses on the links between the various levels and the ways conflicts can be resolved, and solutions negotiated, between different stakeholders, from local to national levels.

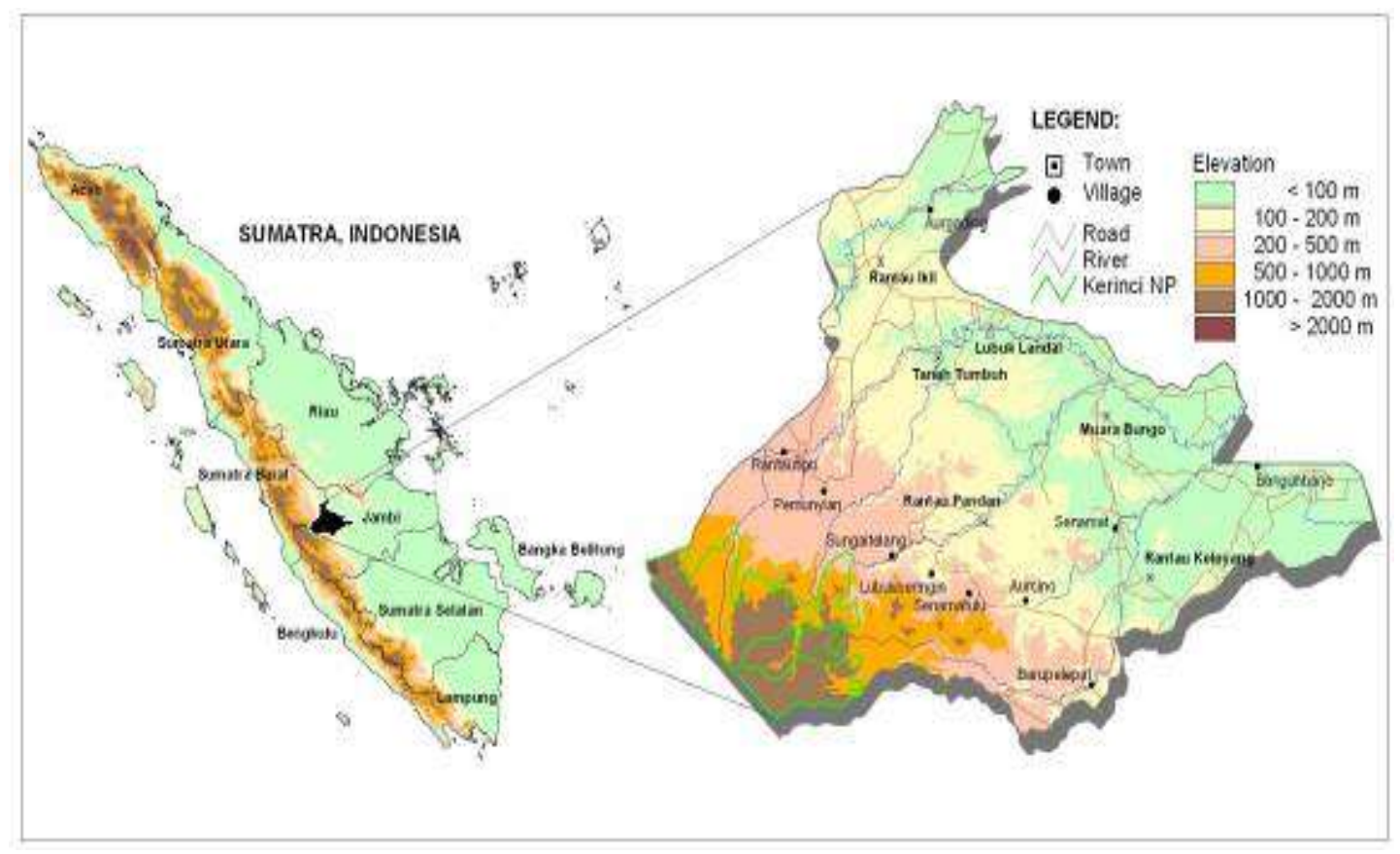

Figure 1. Location of Bungo district, Jambi province, Indonesia 


\section{Background of ecology, history and land use in Jambi}

Bungo district is located in the lowlands and foothills of the Bukit Barisan mountain range in the centre of Sumatra and is administratively part of Jambi province (Figure 1.). The land-use mosaic of Bungo district (716 000 ha) consists of $10 \%$ protected, natural forest in the foothills, with low amounts of disturbance; $34 \%$ of logged-over/degraded forests; $50 \%$ of agriculture; and $6 \%$ of other land-use types (settlements, rivers etc) (Bungo dalam Angka 2002). The agricultural landscape includes remnants of the traditional upland agriculture based on fallow rotations and upland rice as staple, intensive paddy cultivation along rivers, complex multistrata rubber agroforest on the peneplains, home-gardens and monocultural plantations of rubber and oil palm.

Land-use change and increases in human population density during the last century have been distinctly non-linear, with a first wave of migrants from elsewhere in Indonesia (mostly Java and northern Sumatra) arriving during 1905-1925, and a second starting around 1980.

Dutch conquest in 1906 brought Jambi (and the neighbouring sultanate of Damasraya that is now part of West Sumatra province) under the control of the colonial administration and opened the area for plantation agriculture (Locher-Scholten 1994, 2009 ${ }^{1}$ ). Rapid adoption by smallholders in the area of the newly introduced Hevea brasiliensis ('para rubber') transformed the landscape and beat attempts at establishing large-scale plantations (Samson 1913, Pekelharing 1925, van der Meulen 1936). The area benefitted from the 1920s rubber boom and farmers planted so much rubber that labour availability, not land area planted to rubber, was the primary constraint to production. Rubber exports partly replaced rotan and, after the rubber trees were established and intercropped rice became scarce, the province became dependent on rice imports from elsewhere in Indonesia, which it could afford owing to the price of latex. In periods of high rubber prices, migrant labour from the Kerinci mountains and/or Java ${ }^{2}$ added to the labour force; when rubber prices declined (and Kerinci's coffee or cinnamon boomed) the labour force voted with their feet.

\footnotetext{
${ }^{1}$ Locher-Scholten provides an interesting perspective on how the long-term sibling rivalry between Palembang and Jambi affected the relationship between both and also the centre of colonial power, and how the slow embrace by Jambi of the unitary Republic of Indonesia during the struggle for Independence lead to the incorporation of Jambi into a Central Sumatra province, governed from Padang. After the 1958 break in relations between Padang and Jakarta, Jambi became a province in its own right, with the Bungo area governed from Jambi city.

${ }^{2}$ Javanese contract labourers returning from North Sumatra after completion of their contract settled in Jambi in the early 1920s, starting one of the villages characterised in the ASB Phase 1 and Phase 2 reports (van Noordwijk et al. 1995, Tomich et al. 1998).
} 


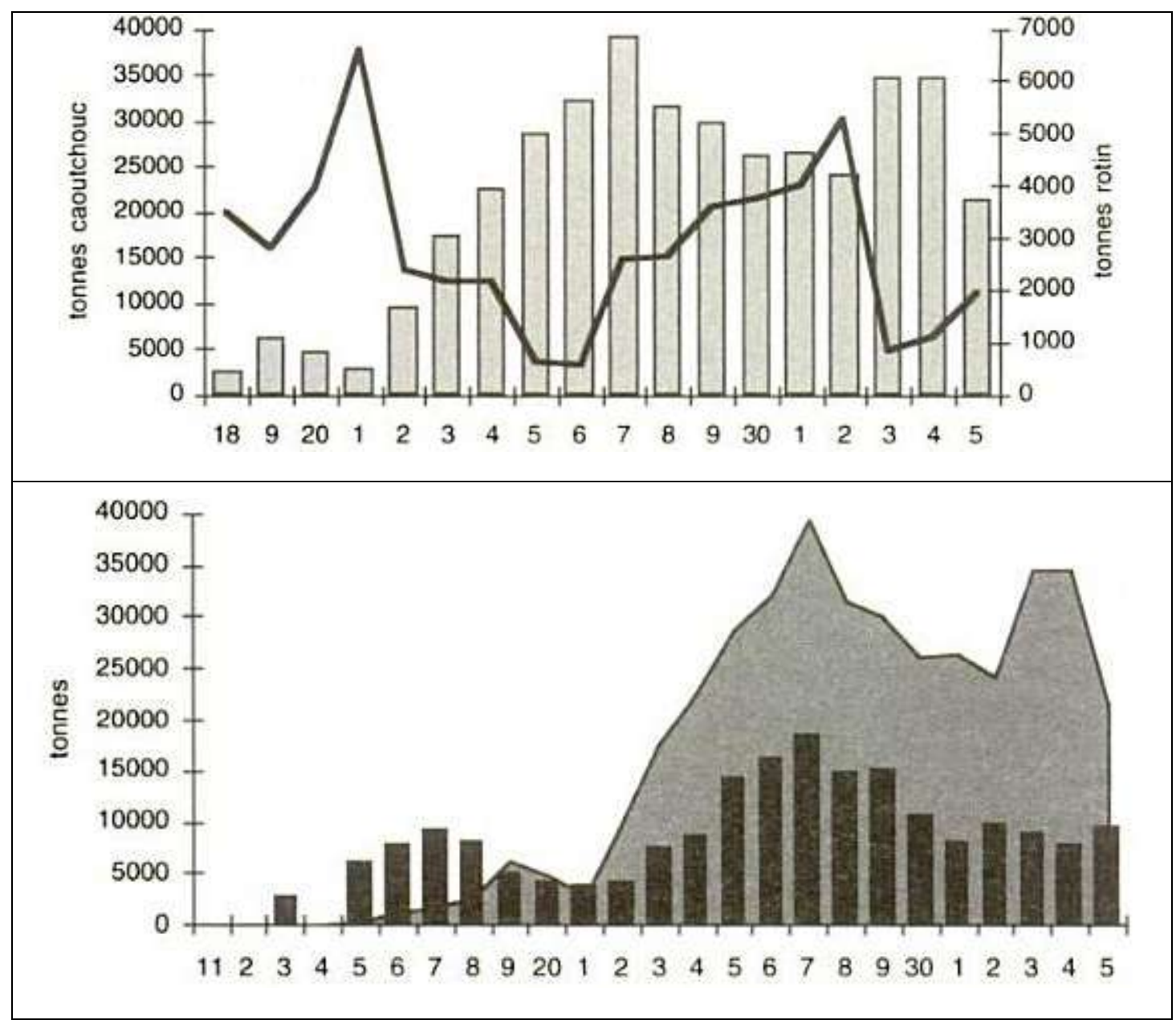

Figure 2. Upper panel: Statistics of rubber (caoutchouc; bars) and rotan (rotin; line) export from Jambi in the period 1918-1935. Lower panel: rubber export and rice import, Jambi, 1911-1935, according to Guillaud (1999)

By the 1930s, Jambi had become a backwater with most of the economy based on rubber and the Batanghari River still the dominant mode of transport. The political elite of Jambi did not give full support to the revolutionary government during the struggle for Independence in 1945-49 (instead trying to set up Jambi as a separate entity within a federal Indonesia). Consequently, the area was annexed to West Sumatra after Independence, only to re-emerge as a separate province in 1958 after a fall-out between the national government and the political leadership in West Sumatra. Big change in Jambi came, however, in the 1970s after the New Order regime promoted logging as a commercial activity, completed the trans-Sumatra highway and brought in a 'transmigrant' population, mostly from Java (Levang 1997). In the 1990s, this was followed by the establishment of large-scale oil palm plantations (protected from competition from independent smallholders, so as not to repeat the story of rubber).

Characterisation of land-use change in the early 1990s by the Alternatives to Slash and Burn project phases 1 and 2 (van Noordwijk et al. 1995, Tomich et al. 1998) captured the end-phase of commercial logging and the transition of the transmigration villages from an orientation on food crops to livelihoods based on rubber and oil palm. The development of secondary roads, such as the Muara Bungo-Muara Kuamang road, was directly linked to change in land use. 
As documented in detail by Miyamoto (2006a,b 2007), the increase in land-use intensity may have actually anticipated the increased availability of labour that would make large rubber areas profitable, through share-tapping arrangements. According to local custom, planting trees brought communal land under private control and a small number of tappable rubber trees per hectare was enough to establish a claim. The emphasis was thus on extensive rubber gardens, while the local rules in many villages established 'fallow rotation reserves' (locally called sesap-nenek or 'ancestors' bush') where tree planting was not allowed, so that after the rice was harvested the land would return to the common pool (van Noordwijk et al. 2008).

While commercial logging activities sanctioned by government concessions stopped in 2000 , loss of natural forest cover has continued and there is not a single example where the Indonesian Selective Logging system aimed at allowing regrowth of the forest for a second round of logging after 30 years has worked. Throughout Jambi, the increased accessibility of the logged-over forest by the network of logging trails connecting to public roads, the presence of a labour force brought in for the logging operations and the policy vacuum at the end of a logging concession gave the appearance of a 'free-for-all' phase of illegal logging, land claims and conversion. Oil palm concessions were planned and licensed by the provincial government for virtually all logged-over forests, often including large tracts of smallholder managed (and 'owned') rubber agroforest. The direct link between local government and Jakarta-based elites was severed in the 1997/1998 Reformasi period, giving more chance to local elites and entrepreneurs.

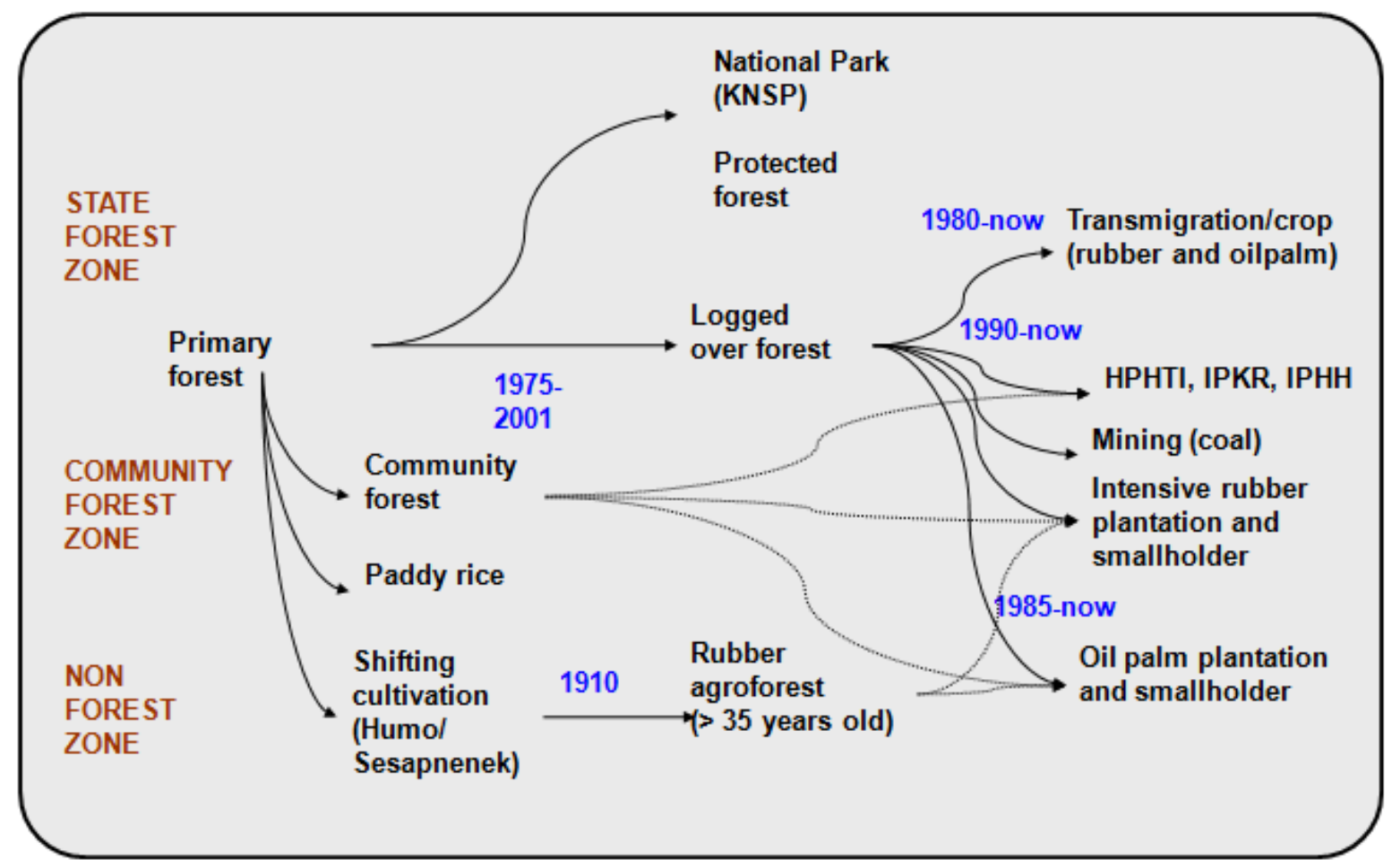

Figure 3. Land-use/-cover trajectories in Bungo district, Jambi province (based on focus groups at the BAPPEDA office in Muara Bungo) 
The provincial forestry authorities became (and so far remain) committed to the establishment of industrial timber ('fastwood') plantations as a way to feed the pulp mills in Jambi and neighbouring Riau, providing a legitimation of 'salvage logging' of the 'degraded forest' in the process. Open-cast mining for coal in the foothills and for gold in the fluvial sand deposits of the lowlands became a major threat to local environmental quality while providing some income opportunities that exceeded the returns from rubber tapping. Relaxation of the rules for oil palm processing plants allowed the emergence of small- and medium-scale oil palm production outside of the large-scale plantations and their outgrower schemes. With the volatility of rubber and oil palm prices in the last decade, each subject to separate dynamics, ideas about which will provide the highest return to labour have also been volatile, but a mixed portfolio is likely to be the best choice for the coming decades and will be competitive with returns from unskilled urban labour. There still is a positive influx of migrants, although many of the local youth focus on education and skilled urban jobs. A brief summary of the timeline of land-use change in Jambi is provided in Figure 3.

Agriculture is still the main source of livelihoods in Bungo district. Rubber and oil palm are the two major agricultural commodities that contribute in cash income to the local community. The major part (60\%) of rubber latex comes from rubber agroforest gardens, based on seedling rubber grown in a secondary forest environment owned by smallholder farmers. The remainder comes from more intensively managed stands ('monoculture') with clonal selections of grafted rubber that is also mostly managed by smallholders. Oil palm is mainly produced in monocultural stands managed by plantation companies and/or owned by transmigrants in outgrower schemes, with some local entrepreneurs starting 'independent' oil palm (Feintrenie et al. 2010). Paddy rice fields are still maintained by the local community to maintain food security, complementing food bought from elsewhere. Bungo district is in a transition from the matrilineal land inheritance tradition of West Sumatra to the mixed patterns seen elsewhere in Sumatra: paddy rice fields tend to be inherited through the female line, while rubber gardens are inherited through either male or female lines (Suyanto and Otsuka 2001, Suyanto et al. 2001).

Regarding conservation of biodiversity, the geographical position of Bungo district is interesting because in the west it borders the Kerinci Seblat National Park (the largest park in Sumatra) at higher elevation and in the past provided ecological connectivity to the Bukit Dua Belas National Park (east of Bungo). The rubber agroforests that were first developed along the rivers in the beginning of the 20th centrury became an ecological corridor that connected to the lowland protected areas. Current pressure on conversion, however, means that only a number of 'stepping stones' are left. The landscape mosaic of forest and rubber agroforest in Bungo district provided livelihoods for a human population of about 50 persons per $\mathrm{km}^{2}$ with active rejuvenation of forest species (Tata 2008). The riparian zone connectivity between protected areas in the region through rubber agroforests is, however, not yet recognised in conservation planning and does not have active policy support.

Forests and rubber agroforests are conceptual sites where various stakeholders interact, particularly regarding how to improve livelihoods in Bungo. Forest and rubber agroforests are the main natural capital in the district and, so, compared to other land-use types in Bungo, the amount of area dedicated to these land uses has been decreasing from year to year (Figure 3.). Forests began to deplete rapidly in the 1980s when large transmigration programs were initiated in conjunction with rubber and oil palm plantations (36 $000 \mathrm{ha}$ ) and release of permissions for forest concessions (Kurniadi and Taher 2008, Ekadinata and Vincent 2008). After the Reformasi era began in 1998, 
illegal logging and forest encroachment became the major deforestation drivers in Bungo. And like any other district in Indonesia, the reformation of governance systems from centralised to decentralised (in 2001), has influenced natural resources management owing to changes of policies at district, provincial and national levels. Complex rubber agroforests were depleted rapidly, beginning in 2005, owing to the increased price of rubber and oil palm (more than $100 \%$ of the usual price). The high prices inspired farmers to convert their complex rubber agroforests to monoculture.

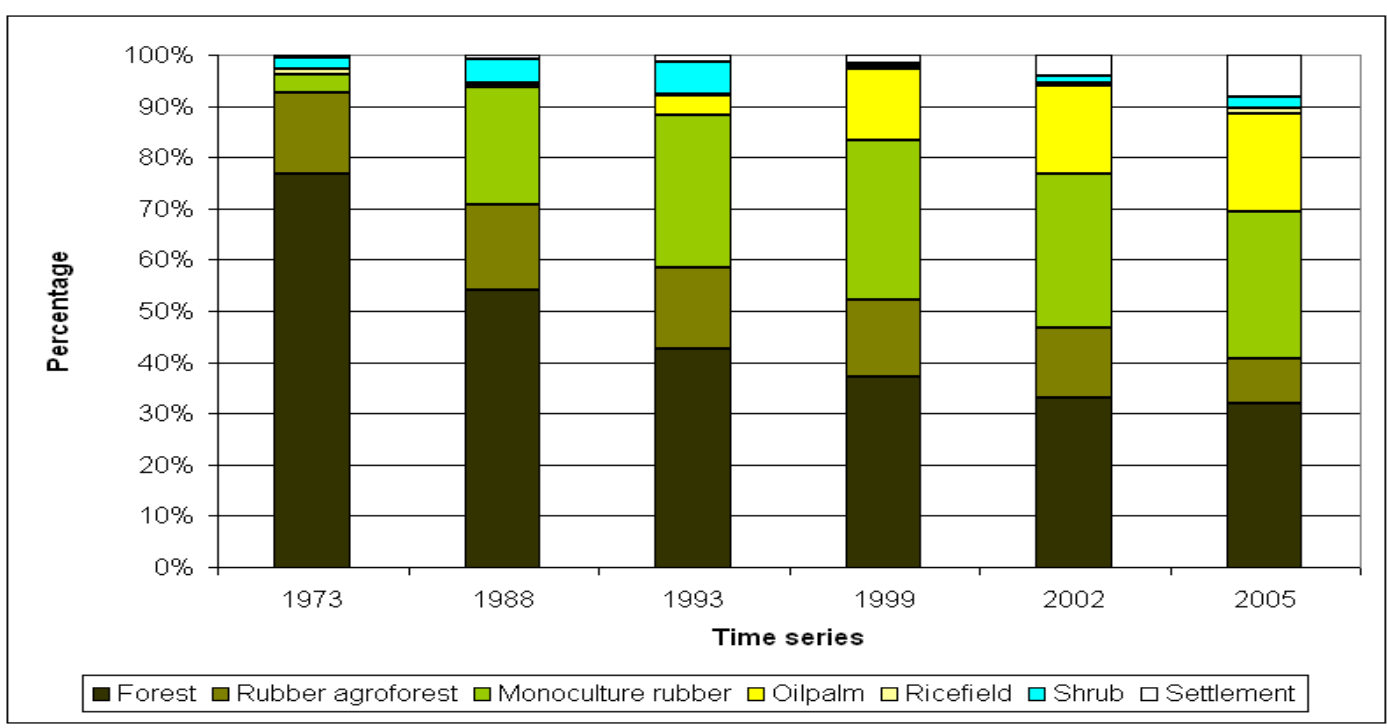

Source: World Agroforestry Centre Southeast Asia Program, Spatial Analysis Unit, 2008

Figure 4. Land-cover dynamics in Bungo district from 1973 to 2005

The main difference between forests and rubber agroforests, besides land-cover properties, is the tenurial system (de Foresta et al. 2000, Michon 2005). At community level, usually forest is owned and managed communally while rubber agroforests are personal property. At government level, government has full power and rights over the state forests and recognise rubber agroforests that are located in agricultural zones as personal property. Compared to forests, rubber agroforests have clearer tenurial status that is acknowledged by different stakeholders.

Local communities perceive forests and rubber agroforests as sources of livelihoods (that is, timber, non-timber forest products, land for agriculture), while private companies and local governments are more interested in forests then rubber agroforests because private companies usually use the natural resources found in forests for their business (for example, land, gold, coal, timber) and governments see forests as sources of regional revenue (Pendapatan Asli Daerah). 


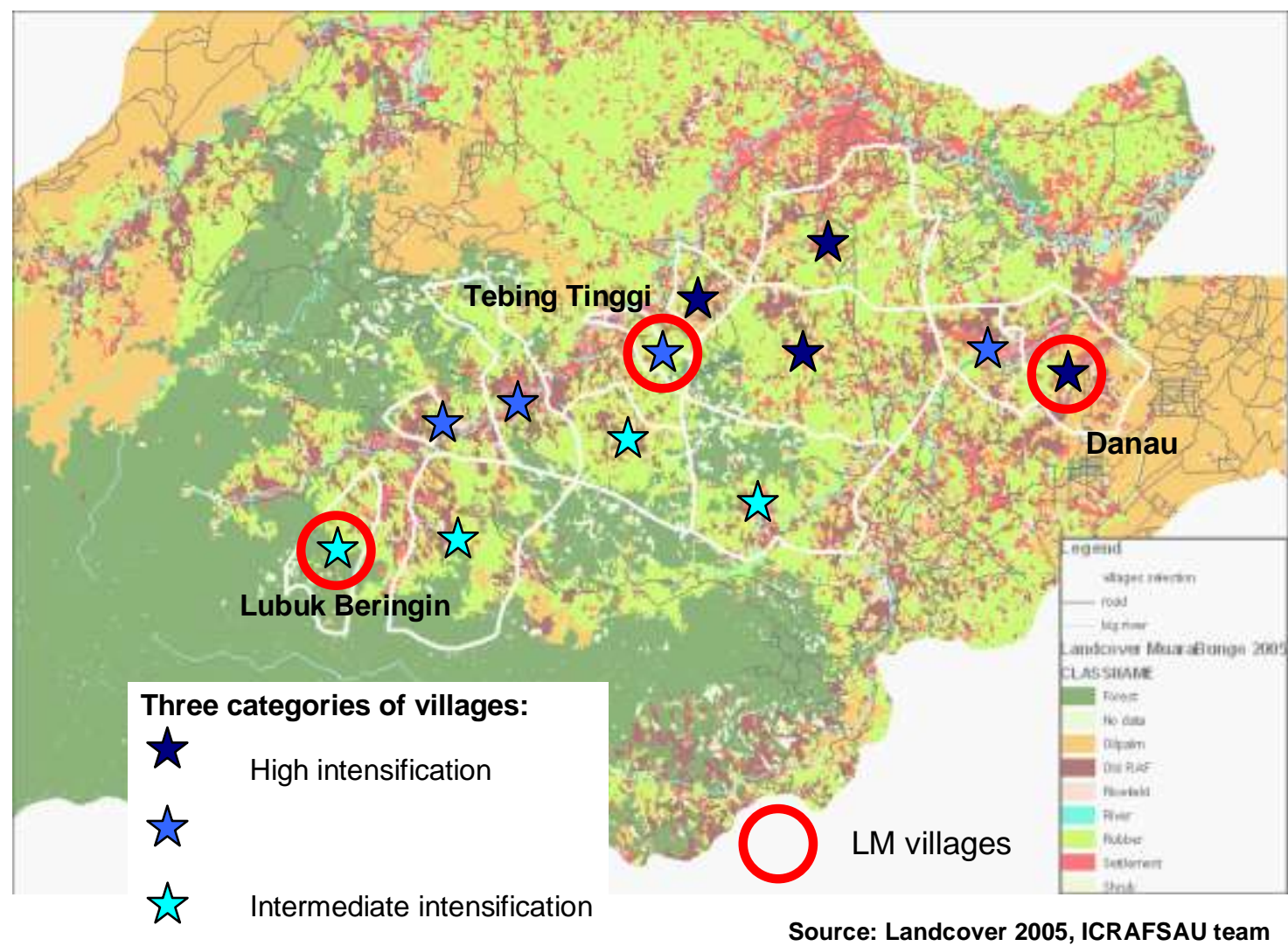

Figure 5. Location of the three study villages selected for the Landscape Mosaics project, from an initial 12 villages along the Bungo River (adapted from Therville 2008)

Different stakeholder interests in the Bungo landscape were reflected in the land-use types that occurred in the area. Those interests were classified by Therville et al. (2011) in three types of landuse gradient: (i) low intensification (with forest and complex rubber agroforests dominating the landscape); (ii) intermediate intensification (with complex-to-simple rubber agroforests dominating); and (iii) high intensification (with simple rubber agroforests, monoculture rubber and oil palm). Blending those different stakeholder interests into one perception of the landscape's resourceswhich would be expected to provide livelihoods and, at the same time, a sustainable, healthy environment - would contribute to the improvement of natural resource management in Bungo district. Understanding how governance works at local and district levels would support improvement through strengthened collaboration and minimised conflicts between stakeholders.

Hence, three villages in Bungo district were selected based on different village landscape mosaic gradients (Figure 5): (i) Lubuk Beringin village, Bathin III Ulu subdistrict (low intensification); (ii) Tebing Tinggi village, Muko-muko Bathin VII subdistrict (intermediate intensification); and (iii) Danau village, Pelepat Ilir subdistrict. Criteria for village selection was developed based on consultation with multiple stakeholders and landscape analysis of the district (Feintrenie et al. 2010). 
Table 1. Stakeholders' roles and responsibilities

\begin{tabular}{|c|c|c|c|}
\hline Stakeholder groups & NRM activities & Roles and responsibilities & $\begin{array}{l}\text { Form of benefit gained } \\
\text { from NRM activities }\end{array}$ \\
\hline $\begin{array}{l}\text { Governments } \\
\text { 1. District level } \\
\text { a) Head of district (Bupati) and regional } \\
\text { parliament (DPRD) } \\
\text { b) District planning board (BAPPEDA) } \\
\text { c) Forest and estate crop department (Dinas } \\
\text { Kehutanan dan Perkebunan) } \\
\text { d) Labour and transmigration department (Dinas } \\
\text { Tenaga Kerja dan Transmigrasi) } \\
\text { e) Mining and environmental department (Dinas } \\
\text { Pertambangan dan Lingkungan Hidup) } \\
\text { f) Trade and tourism department (Dinas } \\
\text { Perdagangan dan Pariwisata) } \\
\text { g) National land agency (Badan Pertanahan } \\
\text { Nasional) } \\
\text { g) Head of subdistrict (Camat) } \\
\text { h) Head of the village (Kepala Desa) and village } \\
\text { council } \\
\text { 2. Provincial level } \\
\text { a) Governor (Gubernur) and regional parliament } \\
\text { (DPRD) } \\
\text { b) Provincial planning board (BAPPEDA) } \\
\text { c) Forest and estate crop department (Dinas } \\
\text { Kehutanan dan Perkebunan) } \\
\text { d) Labour and transmigration department (Dinas } \\
\text { Tenaga Kerja dan Transmigrasi) } \\
\text { e) Mining and environmental department (Dinas }\end{array}$ & $\begin{array}{l}\text { *Intensive rubber (smallholder } \\
\text { and plantation) } \\
{ }^{*} \text { Community forest } \\
{ }^{*} \text { Rubber agroforest } \\
\text { conservation } \\
\text { *Transmigration } \\
\text { *Mining } \\
{ }^{*} \text { Oilpalm plantation } \\
{ }^{*} \text { Logging activities } \\
{ }^{*} \text { HTI/HTR } \\
{ }^{*} \text { Protected forest }\end{array}$ & $\begin{array}{l}\text { In general, government roles are: } \\
\text { (ii) legalise the spatial planning final } \\
\text { product } \\
\text { (iii) issue permissions to private sector } \\
\text { (logging, mining, plantation, HTI/HTR) to } \\
\text { operate } \\
\text { (iv) recognise and support community } \\
\text { forests and other community NRM activities } \\
\text { (v) delineate protected areas based on } \\
\text { consultation with the local people } \\
\text { Different rights and power per level: } \\
\text { (i) A district has the right to propose any } \\
\text { NRM activities located in their area } \\
\text { (ii) A province has right to approve or not } \\
\text { approve a district's NRM proposal on lands } \\
\text { with the status of Area for Other Purposes } \\
\text { (APL) and Protected Forests } \\
\text { (iii) National government has the right to } \\
\text { approve any NRM proposal that relates to } \\
\text { forest areas with the status of Production } \\
\text { Forests and National Park }\end{array}$ & $\begin{array}{l}{ }^{*} \text { Regional own-source } \\
\text { revenue (Pendapatan Asli } \\
\text { Daerah): from transportation } \\
\text { taxes, taxes paid by private } \\
\text { sectors } \\
{ }^{*} \text { General Allocation Fund } \\
\text { (Dana Alokasi Umum) from } \\
\text { the central government }\end{array}$ \\
\hline
\end{tabular}




\begin{tabular}{|c|c|c|c|}
\hline Stakeholder groups & NRM activities & Roles and responsibilities & $\begin{array}{l}\text { Form of benefit gained } \\
\text { from NRM activities }\end{array}$ \\
\hline $\begin{array}{l}\text { Pertambangan dan Lingkungan Hidup) } \\
\text { f) Trade and tourism department (Dinas } \\
\text { Perdagangan dan Pariwisata) } \\
\text { g) National land agency (Badan Pertanahan } \\
\text { Nasional) } \\
\text { 3. National } \\
\text { (a) Board of Kerinci Seblat National Park (Balai } \\
\text { Taman Nasional Kerinci Seblat) } \\
\text { (b) Ministry of Forestry (MoF) } \\
\text { (c) National land agency (Badan Pertanahan } \\
\text { Nasional) } \\
\text { (d) Bank Rakyat Indonesia: provides loan for } \\
\text { agricultural revitalization program }\end{array}$ & & & \\
\hline $\begin{array}{l}\text { Local community (village) } \\
\text { 1. Farmers } \\
\text { 2. Customary institution } \\
\text { 3. Village leaders } \\
\text { 4. Farmers' groups } \\
\text { 5. Women's groups } \\
\text { 6. Youth groups }\end{array}$ & $\begin{array}{l}\text { *Smallholder rubber } \\
\text { monoculture } \\
\text { *'Smallholder oil palm } \\
\text { "Rubber intercropping } \\
\text { * Rubber agroforest } \\
\text { conservation } \\
\text { "Community forests } \\
\text { "Mining } \\
\text { "Paddy field activities } \\
\text { "Logging activities }\end{array}$ & $\begin{array}{l}\text { * First actor directly involved with NRM, } \\
\text { focusing on optimising land use } \\
\text { * Have right to propose NRM activities to other } \\
\text { stakeholder groups (government, private } \\
\text { sector, conservation agencies) } \\
\text { * Participate in government programs } \\
\text { * Have right to refuse an NRM proposal from } \\
\text { private sector or other organizations }\end{array}$ & $\begin{array}{l}\text { * Daily income from rubber } \\
\text { * Bi-weekly income from oil } \\
\text { palm } \\
\text { * Compens ation payments it } \\
\text { their area falls under mining } \\
\text { or logging } \\
\text { " Yearly income from paddy } \\
\text { field activities } \\
\text { * Secure timber stocks from } \\
\text { community forests }\end{array}$ \\
\hline $\begin{array}{l}\text { Private sector } \\
\text { 1.Foreign investors: mining companies from } \\
\text { Korea and Taiwan, palm oil company from } \\
\text { Malaysia } \\
\text { 2.Local investors: coal mining company, logging }\end{array}$ & $\begin{array}{l}\text { *Oil palm plantation } \\
\text { *Rubber plantation } \\
\text { "Logging activities } \\
\text { "HTI/HTR } \\
{ }^{*} \text { Transmigration }\end{array}$ & $\begin{array}{l}\text { * Propose NRM activities to the government } \\
\text { before starting their business activity } \\
\text { * Ask local community permission to conduct } \\
\text { their business activity in the area }\end{array}$ & Profit for the company \\
\hline
\end{tabular}




\begin{tabular}{|c|c|c|c|}
\hline Stakeholder groups & NRM activities & Roles and responsibilities & $\begin{array}{l}\text { Form of benefit gained } \\
\text { from NRM activities }\end{array}$ \\
\hline $\begin{array}{l}\text { company (PT Rimba Karya Indah, PT Mugitriman } \\
\text { Intercontinental, PT Inhutani V, PT Merangin } \\
\text { Karya Sakti), Wira Karya Sakti (HTI), } \\
\text { transmigration-oilpalm plantation (PT Jamika } \\
\text { Raya, PT Sari Aditya Loka), PTPN VI (rubber and } \\
\text { oilplam state plantation) } \\
\text { 3.Rubber factory and traders } \\
\text { 4.Palm oil factory and traders }\end{array}$ & ${ }^{*}$ Mining (coal and gold) & & \\
\hline $\begin{array}{l}\text { Conservation agencies: } \\
\text { 1.International: World Agroforestry Centre and } \\
\text { Center for International Forestry Research } \\
\text { 2.National: KKI Warsi, Yayasan Gita Buana, } \\
\text { Pusat Studi Hukum dan Kebijakan Otonomi } \\
\text { Daerah (Study Center for Legislation and Policy } \\
\text { on Regional Autonomy) }\end{array}$ & $\begin{array}{l}{ }^{*} \text { Rubber intercropping } \\
{ }^{*} \text { Community forest } \\
{ }^{*} \text { Rubber agroforest } \\
\text { conservation }\end{array}$ & $\begin{array}{l}\text { *Provide information and technical skills } \\
{ }^{*} \text { Facilitate community development activities } \\
\text { focused on livelihoods and conservation } \\
\text { aspects } \\
\text { *Provide recommendations on livelihood and } \\
\text { conservation to other stakeholders, particularly } \\
\text { to decision makers }\end{array}$ & $\begin{array}{l}\text { Lessons learned in the } \\
\text { NRM process at different } \\
\text { levels that can be shared } \\
\text { with other areas }\end{array}$ \\
\hline
\end{tabular}


Table 2. Stakeholders in the main land-use categories

\begin{tabular}{|c|c|c|c|c|c|}
\hline \multirow[b]{2}{*}{ Village } & \multirow{2}{*}{$\begin{array}{l}\text { Land-use } \\
\text { types }\end{array}$} & \multicolumn{4}{|c|}{ Stakeholders involved } \\
\hline & & $\begin{array}{l}\text { Conservation } \\
\text { agencies }\end{array}$ & Governments & $\begin{array}{l}\text { Local } \\
\text { community }\end{array}$ & Private sector \\
\hline $\begin{array}{l}\text { Lubuk } \\
\text { Beringin }\end{array}$ & $\begin{array}{l}{ }^{*} \text { Forests } \\
\text { *Ladang } \\
{ }^{*} \text { Rubber } \\
\text { agroforest } \\
\text { * Paddy rice } \\
\text { field } \\
\text { * Settlement }\end{array}$ & $\begin{array}{l}{ }^{*} \text { World } \\
\text { Agroforestry } \\
\text { Centre } \\
{ }^{*} \text { KKI Warsi } \\
\text { (Integrated } \\
\text { Conservation } \\
\text { and } \\
\text { Development } \\
\text { Project, Kerinci } \\
\text { Seblat National } \\
\text { Park) } \\
{ }^{*} \text { RUPES } \\
\text { consortium } \\
\text { (World } \\
\text { Agroforestry } \\
\text { Centre, KKI } \\
\text { Warsi, } \\
\text { Yayasan Gita } \\
\text { Buana) }\end{array}$ & $\begin{array}{l}{ }^{*} \text { Forestry and } \\
\text { Estate crop } \\
\text { department } \\
{ }^{*} \text { Agriculture } \\
\text { department } \\
{ }^{*} \text { Public works } \\
\text { department } \\
{ }^{*} \text { Mining, Energy } \\
\text { and Environment } \\
\text { department } \\
{ }^{*} \text { Industry, trade } \\
\text { and cooperation } \\
\text { department }\end{array}$ & $\begin{array}{l}\text { * Farmers' groups } \\
\text { * Women's } \\
\text { groups } \\
\text { * Women's } \\
\text { cooperative } \\
\text { organization } \\
\text { (Koperasi Dahlia) } \\
\text { * Youth } \\
\text { organization } \\
\text { * Micro-hydro } \\
\text { group } \\
\text { * Village leaders } \\
\text { * Village council } \\
\text { * Customary } \\
\text { leaders }\end{array}$ & none \\
\hline $\begin{array}{l}\text { Tebing } \\
\text { Tinggi }\end{array}$ & $\begin{array}{l}{ }^{*} \text { Rubber } \\
\text { agroforest } \\
\text { * Paddy rice } \\
\text { field } \\
\text { * Ladang } \\
\text { * Settlement }\end{array}$ & none & $\begin{array}{l}{ }^{*} \text { Forestry and } \\
\text { Estate crop } \\
\text { department } \\
{ }^{*} \text { Agriculture } \\
\text { department } \\
{ }^{*} \text { Public works } \\
\text { department } \\
\text { * Industry, trade } \\
\text { and cooperation } \\
\text { department }\end{array}$ & $\begin{array}{l}\text { * Farmers' groups } \\
\text { for estate crops } \\
\text { and paddy rice } \\
\text { fields } \\
\text { * Village leaders } \\
\text { * Village council } \\
\text { * Customary } \\
\text { leaders }\end{array}$ & none \\
\hline Danau & 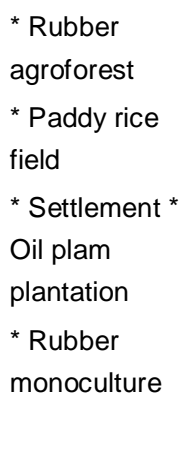 & $\begin{array}{l}\text { World } \\
\text { Agroforestry } \\
\text { Centre }\end{array}$ & $\begin{array}{l}{ }^{*} \text { Forestry and } \\
\text { Estate crop } \\
\text { department } \\
{ }^{*} \text { Agriculture } \\
\text { department } \\
\text { * Public works } \\
\text { department } \\
{ }^{*} \text { Industry, trade } \\
\text { and cooperation } \\
\text { department }\end{array}$ & $\begin{array}{l}\text { * Farmers' groups } \\
\text { * Yayasan } \\
\text { Pendidikan } \\
\text { Agama (Religious } \\
\text { Education } \\
\text { Foundation) } \\
\text { * Village leaders } \\
\text { * Village council } \\
\text { * Customary } \\
\text { leaders }\end{array}$ & $\begin{array}{l}\text { PT } \\
\text { Megasawindo } \\
\text { (oil palm } \\
\text { company) }\end{array}$ \\
\hline
\end{tabular}




\section{Stakeholder identification}

Tables 1 and 2 provide an overview of the stakeholders as identified for this study. Current livelihoods and conservation issues in Jambi province, if mapped into different quadrants of an XY graph with conservation, zero profitability, intensification and no environmental services as axis, will consist of stakeholders as mapped in Figure 6: (i) Quadrant 1 (Conservation-Intensification) as the ideal zone where conservation could give direct financial benefit; (ii) Quadrant 2 (ConservationZero Profitability) as often happens with conservation based on respect and high awareness, with limited non-financial benefit; (iii) Quadrant 3 (Zero Profitability-No Environmental Services) is activities that give little to environmental services and sustainable financial benefit; and (iv) Quadrant 4 (No Environmental Services-Intensification), which is commonly encountered in productive areas with a focus on profiting as much as possible with little contribution to the maintenance of the landscape's environmental services. In the real world, quadrants 3 and 4 occur most often, particularly when pressure for land is high with little awareness of conservation.

\subsection{Stakeholders at landscape/district level}

Based on Figure 6, stakeholders in Jambi province can be grouped into four major groups based on professional similarity, that is, governments, local community, the private sector and conservation agencies. The government agencies mostly work in quadrants 2 to 4 , private sector activities were mostly found in quadrants 3 and 4 , conservation agencies in quadrant 1 , while the local community was more actively involved in quadrants 1 and 4 . Among the four stakeholder groups, the government has the most decision making powers. The same situation occurs in Bungo district, though excluding the conservation agencies from the stakeholders list. The conservation area is located in Batang Hari district of Jambi province and the northern part of South Sumatra province.

Compared to other districts in Jambi province, Bungo has received a lot of attention from international and national organizations owing to its buffering function for the Kerinci Seblat National Park, which is located in the southern part of the district. Development and its relation to sustainable natural resource management in Bungo has been studied by international and national researchers since 1994 when the area was selected as a benchmark site for the Alternative to Slash and Burn (ASB) program as well as the Smallholder Rubber Agroforestry project, with various follow-on activities (Joshi et al. 2003; Kuncoro et al. 2006, Murdiyarso 2002, Tomich et al. 2002). Subsequently, in 2000, the Center for International Forestry Research (CIFOR) selected the area as a site for its adaptive co-management action research project (Adnan et al. 2008, Fisher, Prabhu and McDougall 2007, Kusumanto et al. 2005, 2006, Yasmi 2007) and follow-on work on governance aspects such as the Collective Action and Property Rights project (Komarudin et al. 2007, Siagian and Neldysavrino 2007, Syamsuddin et al. 2007, de Vries and Sutarti 2006). From 1999 to 2002, national NGO Komunitas Konservasi Indonesia Warung Konservasi (KKI Warsi) implemented a community-based forest management and integrated conservation and development program for Kerinci Seblat National Park in Bungo district (http://www.warsi.or.id/Projects/Projects.htm). Since 2004, the Bungo landscape has also become part of the Rewarding Upland Poor for Environmental Services (RUPES) network of sites where research has been conducted on the concept of rewards or payments for environmental services. 


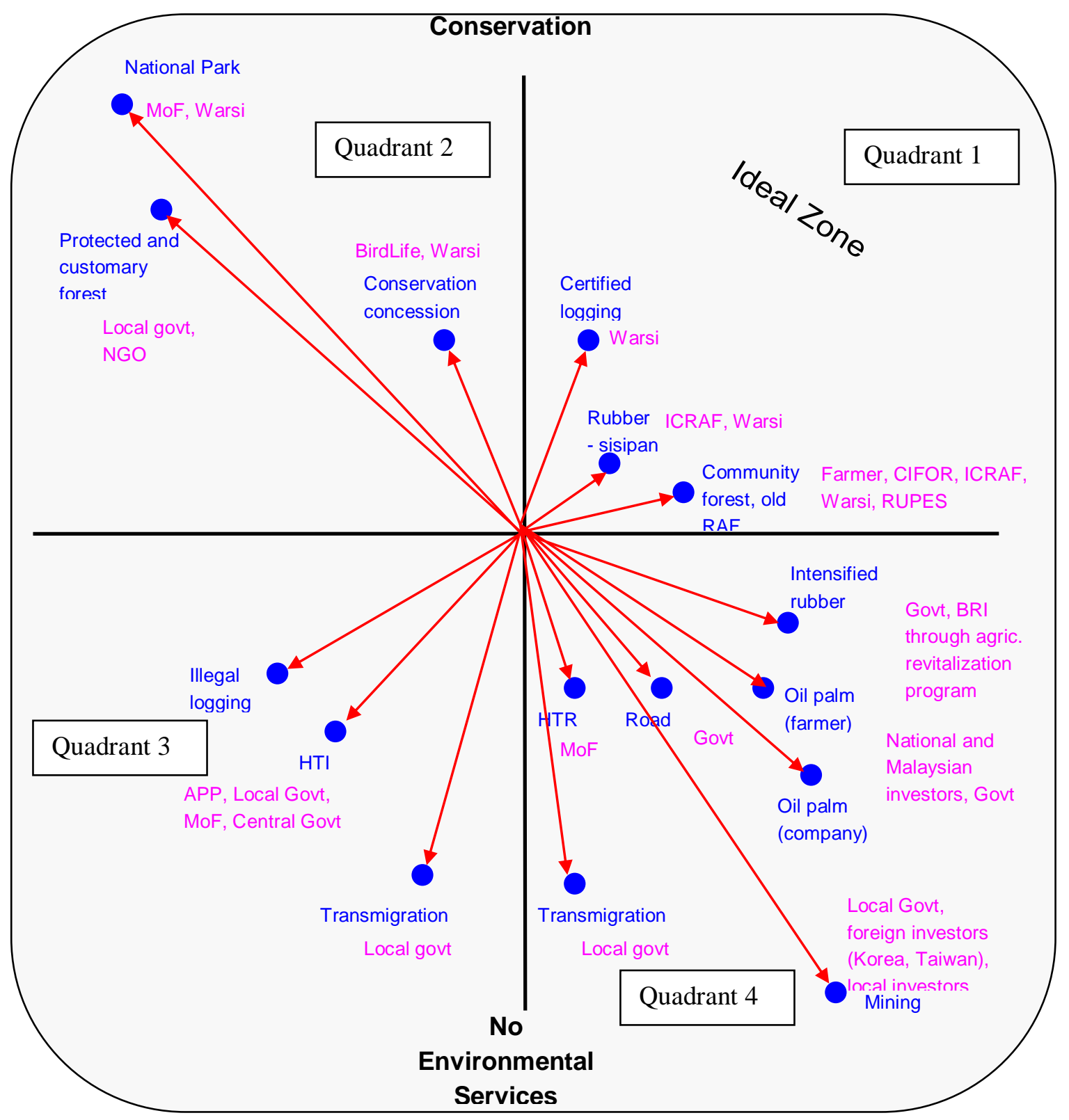

Note: Issues are based on ICRAF-CIFOR-Warsi meeting on 5 May 2008 in Jambi

Figure 6. Land-use/-cover changes and stakeholders' interests in Jambi province

In general, local communities in Bungo district were very much centred on increasing productivity levels, land-use design and improved market access for products from rubber agroforests and other land uses. Regarding improving rubber agroforest productivity, the main issues were damage caused by pests (pigs and different primates, especially the locally endemic leaf monkey) and low latex production. Additionally, there was relatively strong support for oil palm and monoculture rubber plantations. In contrast, for rubber agroforests there was a lack of support from government officials (extension agents) in respect to new technology to improve quality and quantity of rubber production as well as little (or no) recognition and support from local government for farmers' efforts related to watershed protection. 
A centralised land-use designation, which had neglected local people's perspectives in the process, has had the consequence of increasing conflicts over land ownership, most of which have not yet been resolved. Also in Bungo, there was conflict between villagers and timber concession holders. However, at the time of writing the concession holder had withdrawn and no legitimate holder had been appointed to manage the remnant forest, resulting in more intensive encroachment, illegal logging and other extraction of forest products. Despite some apparent dissatisfaction with the process, attempts to plan land use through a participatory approach were led by BAPPEDA (district planning body).

The remoteness of some villages and natural barriers to others has constrained village development. The important threats to conservation are oil palm monoculture plantations, extraction of recently found coal and land conversion in logged-over forests. Apart from offering high incomes in a relatively short period, these options are strongly supported by local government. These activities have the potential to contribute to district government revenue (one consequence of decentralisation is that local governments must find their own means to finance their activities).

In order to support economic development, local government has also allocated areas for transmigration. Labour from the new immigrants, land from local people and initial investment from the private sector was a mix proposed for local economic development through the transmigration program (Levang 1997, Feintrenie and Martini 2010). This typical approach also occurred in Bungo. Although transmigration seems to be an ideal approach and was supported by village elites and subdistrict governments, the rest of the community was not in favour. However, the local community had less power in decisions despite most of the land used for transmigration being secondary forest, old rubber agroforest and fallow, some of which belonged to the community. Additionally, some of the villagers were reluctant to give their land to newcomers under the transmigration scheme because of relationship reasons and economic consequences. In one of the established transmigration sites, the original inhabitants ended up as labourers for the migrants (Sungai Telang village, see Adnan and Yentirizal 2007).

Local desires to speed up the pace of development were also reflected in the policy to encourage private sector business in the area, such as oil palm plantations (through the transmigration scheme) and coal mining. The potential site for a coal mine was Rantau Pandan sub-district. Successful revenues from mining in 2004 triggered the district government to allocate another 2800 ha in 2006 . Rantau Pandan sub-district was also a location of interest for oil palm plantations associated with the transmigration scheme. The forests in Rantau Pandan and Bathin III Ulu sub-district have been converted into a transmigration area with oil palm as the commodity crop. Another local government attempt to enhance district revenue was the proposal to use logged-over forest in Bungo district for industrial forest plantations in collaboration with the Ministry of Forestry and Andalan Pulp and Paper (APP) enterprise. Interestingly, at the same time the local government also proposed the forest for a Reducing Emissions from Deforestation and Degradation (REDD) payment for environmental services scheme, because Jambi province had signed an agreement with an Australian company for carbon trade. The agreement had inspired all district governments in Jambi province to urge their villages to apply for 'village forest' (Hutan Desa) designation (KKI-WARSI 2009, RUPES 2010).

At landscape scale it is clear that the local government (particularly the heads of the district government and the district planning board) had a major role as the decision makers in how natural resources were managed in the region, which is now reflected in the landscape gradient (Feintrenie 
and Martini 2010). The private sector and conservation agencies, as outsiders, contributed to the government decision-making process, while input from the local community was often considered by the local government as a low priority.

\subsection{Stakeholders at local/village level}

At village level, stakeholders in natural resource management can be grouped into internal (official village government, customary leaders, traders, smallholder farmers and collective action groups) and external (governments, the private sector and conservation organisations). Interventions from external stakeholders sometimes affected decision-making at village level, particularly those related to the land-use dynamic in the village.

Of the three focus villages, Lubuk Beringin was the most frequently visited by conservation agencies, which has made the village resistant to activities by entrepreneurs or development agencies that are seen as a threat to their environment, especially to the availability of water resources.

Activities by various conservation agencies in Lubuk Beringin village had attracted district government attention by providing aid and interventions that related to agriculture. Private oil palm companies had visited the Lubuk Beringin village several times, but the village did not accept the company's offers because the villagers consider them of no benefit (see also Akiefnawati et al. 2010 for an analysis of the 2009 award to Lubuk Beringin of the first Hutan Desa contract in Indonesia). Of the three villages, Danau village was the only one that had direct involvement with a private oil palm company (PT Megasawindo).

Generally, drawing from the situation in the three focus villages, village government and customary leaders are acknowledged by the villagers as the most powerful decision makers for any issues that are related to relatively free access land (such as forest). While for land with clear tenurial rights, traders and smallholder farmers are the most powerful decision makers.

Village government was often considered the key stakeholder that could link the village to external stakeholders. The customary leaders were considered the most knowledgeable persons, particularly in customary regulation and village history, therefore they were often asked for advice in dealing with any problems or issues in the village. But in some villages, where customary rules were becoming less respected, the village government was the most powerful decision-making body.

Traders or middlemen in the village were considered rich, having more capital. Usually traders owned large areas in a village (up to 100 ha per trader), which had been inherited or bought from other villagers in the area. Therefore, traders' decisions that led to land-use change could affect the condition of the whole landscape. Also, smallholder farmers had high dependency on traders because the farmers often owed money to the traders, borrowed to meet daily needs. Hence, traders had power over the smallholder farmers.

Smallholder farmers were farmers who owned less than 10 ha. Smallholder farmers were responsible for any activities that occurred on their land, meaning that these farmers had the most power to decide the types of land use in a landscape. However, farmers who didn't have land would usually work as share-tappers or rent land from other farmers with more capital or land and they didn't have the right to manage or change the condition of the land.

Collective action groups were formal or informal institutions that consisted of a mix of smallholder farmers, traders, village governments and customary leaders, depending on the type of group. The 
collective action groups that appeared in the villages were farmer groups, women's groups and youth groups. Details of the names of the collective action groups and other village stakeholders in each village can be found in Annex 3 .

From a gender perspective, men often had more powerful decision-making positions than women, particularly regarding any decision related to forests and rubber agroforests. In village meetings women were invited and attended, but often men were the leaders of the meetings. Women were more responsible for household activities (managing household expenses and domestic life) and educational matters.

Across the landscape, local stakeholder groups in Bungo district were interacting as described in Figure 7. Types of interaction are grouped as coordination, consultation and collaboration.

Coordination is when there is an order line between one stakeholder to the other (for example, an obligation to give formal reports from one stakeholder to the other stakeholder at a higher level). Consultation is when the relationship is about advice, recommendations, information, knowledge and skills shared between stakeholders. Collaboration is when stakeholders are working together to create or produce something.

At village level, horizontal conflicts between villages in Bungo district rarely occurred. Potential conflict between villages was usually about village boundaries. Customary laws and approaches usually applied as first attempt to mediate the horizontal conflict between villages or within the village. If the conflict is too high, then the formal regulation and law agencies may be applied and involved in mediating the conflict.

\begin{tabular}{|c|c|c|c|c|}
\hline Government & $\begin{array}{l}\text { Coordination } \\
\text { Consultation } \\
\text { Collaboration }\end{array}$ & & & \\
\hline $\begin{array}{l}\text { Local } \\
\text { community }\end{array}$ & $\begin{array}{l}\text { Coordination } \\
\text { Consultation } \\
\text { Collaboration }\end{array}$ & $\begin{array}{l}\text { Coordination } \\
\text { Consultation } \\
\text { Collaboration }\end{array}$ & & \\
\hline Private sector & $\begin{array}{l}\text { Coordination } \\
\text { Collaboration }\end{array}$ & $\begin{array}{l}\text { Consultation } \\
\text { Collaboration }\end{array}$ & $\begin{array}{l}\text { Collaboration } \\
\text { Consultation } \\
\text { Coordination }\end{array}$ & \\
\hline \multirow[t]{2}{*}{$\begin{array}{l}\text { Conservation } \\
\text { agencies }\end{array}$} & $\begin{array}{l}\text { Consultation } \\
\text { Collaboration }\end{array}$ & $\begin{array}{l}\text { Consultation } \\
\text { Collaboration }\end{array}$ & $\begin{array}{l}\text { Consultation } \\
\text { Collaboration }\end{array}$ & $\begin{array}{l}\text { Coordination, } \\
\text { Consultation } \\
\text { Collaboration } \\
\text { (consortium) }\end{array}$ \\
\hline & Government & Local community & Private sector & $\begin{array}{l}\text { Conservation } \\
\text { agencies }\end{array}$ \\
\hline
\end{tabular}

Note: the gray areas have high potential for conflict

Figure 7. Matrix of interactions between stakeholder groups in Bungo district

Landscape wide, misperceptions between stakeholder groups in Bungo district occurred mostly happen as vertical conflict between community and government, and community with the private sector (gray area in Figure 7.). Conflict between communities and the government happened mostly 
over tenurial status of forests (less recognition for community property). Minor conflict over the land status of rubber agroforests that were located in state forest zones also had the potential to erupt. Conflict between the local community and the private sector may occurred when local community rights are ignored by private sector interests or when the compensation mechanism of the companies gives very limited financial benefits to the local community (Yasmi 2008). These misperceptions or conflicts usually could be mediated through negotiations that lead to recognition of the rights and responsibilities of the different stakeholders (particularly the rights of the local community that were often ignored) to manage the forests (Endah 2008; Yasmi 2008). Participatory maps were often used as tools to mediate land conflict in the context of natural resource management (Endah 2008, Yasmi 2008, Irawan et al. 2008, Hadi et al. 2008).

Moreover, non-governmental organizations and individuals who continuously monitored and engaged government partners in discourse on forest and natural issues have contributed to shaping local policies. In Bungo, a longstanding interaction among NGOs, research institutes, community groups and government contributed to internalising principles of transparency, openness and participation in government circles (Akiefnawati and Budisetiawan 2010). An improved district land-use plan and the district forestry office's initiative to implement revolving fund projects for local groups were also linked to this network. 


\section{Formal levels of government}

Generally in Indonesia, human population growth is becoming the main challenge to integrating conservation and development in the context of natural resource management. As the population increases rapidly, issues of land accessibility emerge and lead to land acquisition and security conflicts. Various stakeholders have differing legal claims to land resources and these differences often bring conflict (either vertical or horizontal) over who has the right to control and manage the resources. Increasing land scarcity not only has implications for land-cover changes but also for social norms, regulations and property rights. Hence, developing participatory spatial planning and monitoring is a priority as a communication tool between various stakeholders in managing their natural resources. To support participatory spatial planning and monitoring, governance at community and government levels needs to be highlighted.

Over the last ten years in Bungo district, issues of natural resource management that developed as a result of government and community strategies' to improve their livelihoods were mainly related to land tenure and property rights (Adnan et al. 2008). Unclear property rights were considered to be the most important issue to tackle if local communities were to improve their livelihoods. A first step in resolving the land tenure and property rights conflicts was to look at how land and forest uses have been allocated in district land-use plans (Rencana Tata Ruang Wilayah Kabupaten), analyzing how such documents were developed. Land-use planning can serve as a key to tenurial reform even when it is considered to have no direct link with land status (Contreras-Hermosilla and Fay 2006 in Komarudin et al. 2007). Among the natural resource management issues in Bungo, the process to recognise customary forest rights in the district land-use plan can be used as an informative case study about how the formal levels of government in Indonesia are designed to support natural resources management down to the smallest unit (village).

In Indonesia, based on Regulation No. 32/2004, governments are grouped as central and regional governments (that is, provinces and districts). The president is the head of the executive board of the central government that has direct responsibility for the ministries. After the reformation period (from 1999), no direct order was issued from the president to the heads of regional governments. In the current decentralisation era, regional governments have the responsiblity, and right, to manage their own resources. Provinces consist of districts, with coordination within and between provinces and districts. Both provinces and districts have very similar attributes. Regulation agreement processes usually start from the lower level and proceed to the higher level in the regional government, thus: the village, sub-district, district and province. Regulation No. 32/2004 states that the same sequence is valid for regional land-use planning: from village to the provincial level.

Each district (kabupaten) is governed by a district commissioner (bupati). Planning is carried out by BAPPEDA (the planning board) at district level. Each district has a land-use planning committee, responsible for preparing or subcontracting the plan, overseeing its implementation and monitoring the use of allocated lands. This committee, comprised of representatives from BAPPEDA, BPN (National Land Agency), District Forest Office and the District Secretariat, also serves to mediate land conflicts between local communities and private companies. A series of workshops for preparing the five-year district land-use plan were underway during the study period. Led by BAPPEDA, other government agencies (agriculture, forestry, plantation crops) were involved. 
Research and development institutions such as University of Jambi, KKI Warsi, Center for International Forestry Research, World Agroforestry Centre and local communities were consulted. It was suggested that explicit recognition of proposed customary forests should be included in the official land-use maps.

Since 2002 there have been two customary-forest recognition proposals submitted to the Bungo district government: for Batu Kerbau and Bukit Siketan forests, which were adjacent to each other in the Pelepat Ulu sub-district. Both customary forests were located in production forest areas, where conflict over land had occurred between the communities and logging companies (Endah 2008, Pariyanto 2008, Yasmi 2008). The background stories of the two customary forests were similar, beginning in 1970 when logging companies received permission (called HPH) from the Ministry of Forestry and entered the production forests that were considered by the communities as their customary areas. HPH operation in the area during 1970-1998 caused local community access to land and forests to be restricted, reduced the community's cash income and caused floods. Then, in the Reformasi era (1998-2002) almost all HPH stopped operating but illegal logging activities increased, causing the amount of tree stock in the area to decrease. From 2002 to 2004, local communities became aware that they needed to conserve available trees for their future timber stocks. Conservation agencies in the area (KKI Warsi in Batu Kerbau and the Adaptive CoManagement (ACM) project of CIFOR in Baru Pelepat) facilitated the communities' applications for customary land rights recognition from the government.

Batu Kerbau and Baru Pelepat went through long processes to gain recognition of their customary forests (from 2000 to 2002 for Batu Kerbau and 2002 to 2006 for Baru Pelepat (Figure 8)). They developed different strategies to achieve their goals. Batu Kerbau community went straight to the Bupati after they collected all the required documents (that is, a community agreement that documented customary forest regulations, which were complemented by participatory maps of the proposed customary forest area). After public consultation in February 2002, that involved the district secretariat, BPN, Department of Forestry and Plantations, district legal sector, district governance sector, head of the district's customary institutions, media organisations, KKI Warsi and community representatives, an evaluation team was formed (made up of representatives from BPN, Department of Forestry and Plantations, district law sector, district governance sector, district customary institutions, head of Pelepat sub-district and KKI Warsi) to recheck what had been documented by the community and make a recommendation to the Bupati to accept or reject the proposal. The Bupati agreed with the recommendation that the customary forest be recognised and provided an official letter on 16 July 2002 (SK No. 124916 Juli 2002). To have a stronger position in law, the letter of recognition needed to be regulated as a regional regulation (peraturan daerah). But, unfortunately for Batu Kerbau the process stopped at the recognition letter; up to the time of writing there had been no further follow up from the district government to enshrine the recognition in a peraturan daerah.

The Baru Pelepat community went through a slightly different process than Batu Kerbau, learning lessons from what had been done by the latter. Baru Pelepat aimed to get a stronger position in law than just the Bupati's recognition letter in order to have more secure rights. After the community collected the required information, they promulgated the documents as a village regulation (peraturan desa) through a village meeting. Then, the peraturan desa was brought to the district government and, after long discussion, the first draft of the peraturan daerah was formed. The process was finalized after the draft peraturan daerah was approved by the district legislative body 
as Peraturan Daerah Kabupaten No. 32/2006. But the story ended up the same as for Batu Kerbau's letter: no follow up from the district government to take the peraturan daerah kabupaten to the provincial government. This happens not only in Bungo; it is common in all districts in Indonesia for proposals of customary forest rights.

Up until the time of writing, no customary forest rights have been recognized at provincial level (peraturan daerah provinsi) let alone national level (Minister of Forestry decree). This is because there have been no proposals involving more than one district. Customary forest rights, such as those held by Batu Kerbau and Baru Pelepat, are formally known as Traditional Forest Management Rights (Hak Pengelolaan Hutan Adat) with the permission procedure regulated in PP No.34/2002:

- If the proposed area is located in a district or city, permission is given by the bupati or mayor of the city with a copy to the minister, governor and related institution in the local forestry sector.

- If the proposed area crosses two or more districts in the same province, permission is given by the governor with a copy to the minister, bupati or the mayor of the city.

- If the proposed area crosses two or more provinces, permission is given by Minister of Forestry with a copy to the governor and the bupati or the mayor of the city.

The Batu Kerbau and Baru Pelepat customary forests have been acknowledged in the Bungo District Land-Use Plan, but the Ministry of Forestry has not yet legally acknowledged them in the Forest Land-Use Plan Consensus (Tata Guna Hutan Kesepakatan). Permission for logging companies is given based on decisions made at the Ministry of Forestry. The regional governments only have the right to give recommendations to the Ministry of Forestry on current issues at regional level that relate to the area that was proposed by the logging company. Customary forest rights that are acknowledged at district level only are not strong enough to defeat permissions granted by the Ministry of Forestry to logging companies. Therefore, the customary forest rights need to be also formally recognised by the regional and central governments. The same should apply for other treebased land uses (for example, rubber agroforests) that have the potential to be recognised as ecological corridors. 


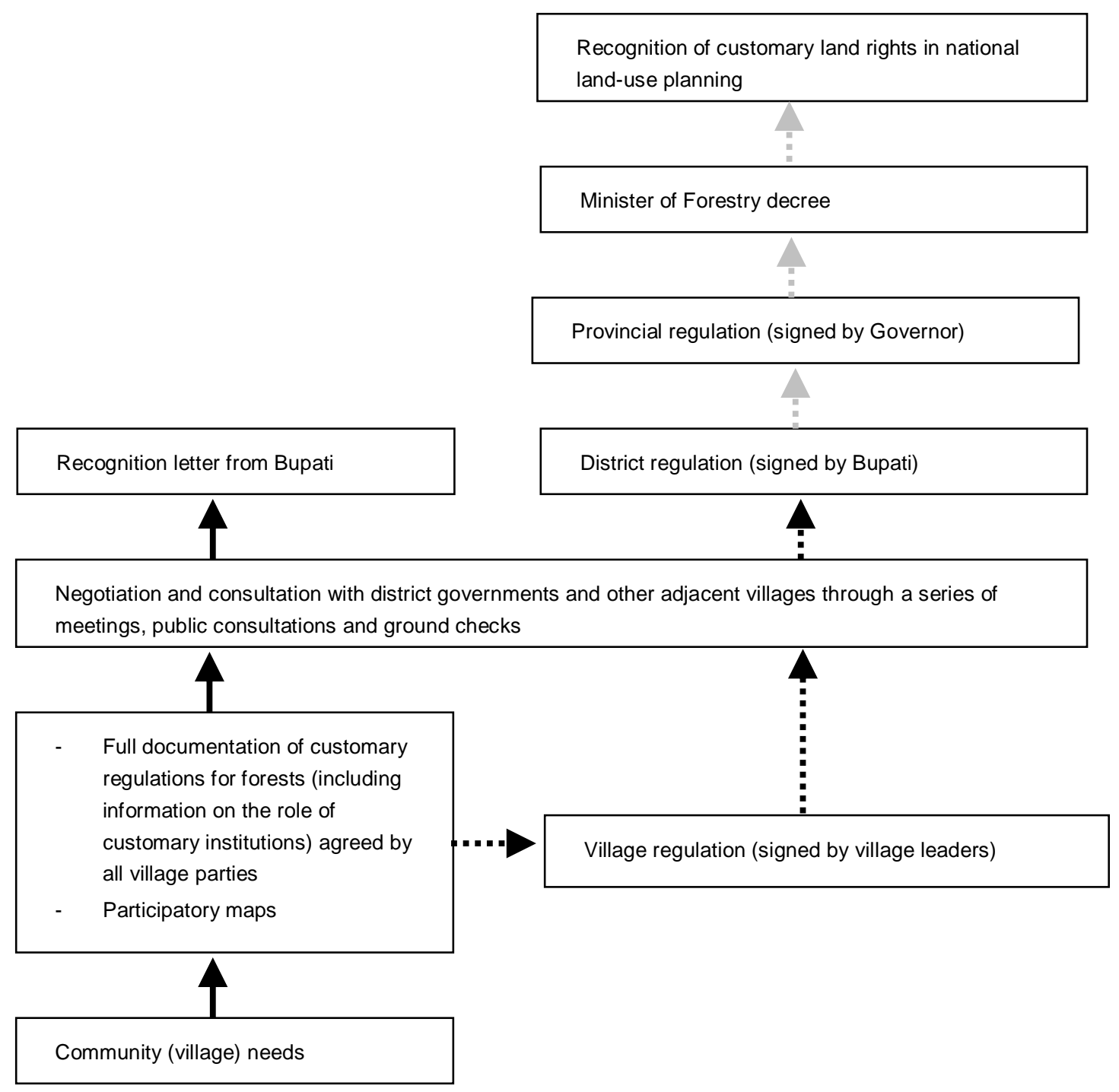

Note:

1. dotted arrow is the process for Baru Pelepat customary forest recognition that took 3-4 years

2. Solid arrow is the process for Batu Kerbau customary forest recognition that took 1-2 years

3. Gray arrow is the future process, based on PP no. 34/2002, which has not yet occured in any place in Indonesia

Figure 8. Process of proposing customary forest land rights in Bungo district 


\section{Governance of natural resources}

Sustainability of natural resources is greatly influenced by the positions of various interest groups. Of the four stakeholder groups at landscape level, the private sector and conservation agencies may drive the trend for natural resources utilization, but local governments and local communities have more authority to manage the natural resources. Communication between local governments and local communities needs to be built and maintained in order to create collaboration between the two levels. Land-use planning documentation, both at community and district levels, should then be able to present information on how to optimise the wise use of natural resources. Hence, the characteristics of both the local community and local government need to be described.

\subsection{Local community level}

The smallest formal administrative unit in Indonesia is the village, which was institutionalised in 1979 by national regulation (UU) No.5/1979. After 1979, local communities that had similar backgrounds and customary attributes (rules, relations and territory) were split into several villages, like Batu Kerbau and Baru Pelepat that came from one local community called Bathin and had the same ancestors and close customary relationships that were still being maintained at the time of our research. National regulation No. 5/1979 notwithstanding, the power of customary institutions to apply customary law has been progressively decreasing.

In the decentralisation era (2001 to the present), national regulation UU No. $5 / 1979$ has been revised by UU No. 32/2004 so that now each village (and other levels of regional administration, that is, district and province) has its own authority to manage its internal affairs. The UU No.32/2004 opened new opportunities for regional government to restructure their formal administrative areas, as long as this did not inhibit the development process. In early 2008, Bungo district (and Jambi as a whole) restructured their villages into a formation that was similar to the old local community before 1979, when community administrative boundaries were managed based on customary territory. In the new structure, kampung has replaced village, with an area slightly bigger than village but smaller than sub-district (for example, several kampung make up the territory of Rio that almost has the same function as a sub-district). This village restructuring in Bungo was proposed through BAPPEDA, beginning in 2005 (Hasan et al. 2008), based on the argument that respect to customary rules was weakening owing to lessening integration between local government and customary rules.

At the time of writing, village restructuring in Bungo was still in transition. In the future, the new structure may affect the way natural resources are regulated, monitored and evaluated particularly at community level. Customary institutions are likely to play major roles in regulating the management of natural resources in the area based on agreed customary rules and social norms. Interestingly, if local customary institutions do take a major role, then new migrants that come from different cultural backgrounds (for instance, from Java via a transmigration program) may need to adjust to the local customs. Nevertheless, some issues to do with land tenure, environmental ethics, cultural respect, elites seizing control and other disincentives that interfere with sustainable management are still relevant. 


\subsubsection{Local tenure}

Generally, local tenurial issues in Bungo mostly related to land ownership, with all types of resources addressed by the land tenurial system. Forests are largely considered communal property accessible for agricultural purposes by village members. At village level, there are two types of land tenure system, that is, 1) communal property; and 2) private property. Communal property can be used with the permission of the customary leaders. Each community member has the same right to gain benefits that improve their livelihood through the communal property. The most common form of land communal property is customary forest and belukar (secondary vegetation), which is controlled and monitored by the community through their representative in the customary institution. The communal property is strengthened by the local people's customary law (Nenek samo di imbo [hutan], puyang samo di seru $=$ Everyone has the same right to manage communal land by planting with short-term agricultural crops only, but the land cannot be private property).

Private property is land acquisition for personal use with land management controlled by the owner. Rubber agroforestry gardens and other land-use types included in the local inheritance system are forms of private property. Private property usually is strengthened by a letter of recognition signed by the head of the village. The letter of land recognition that occurs at village level is a simple letter, which is less expensive than formal land recognition registered and signed by the National Land Agency. The simple land recognition letter documents information about the owner, location (often with a simple sketch), how the land was obtained (for example, purchase, inheritance) and witnesses (that is, persons other than the land owner who know the history of the land's ownership and other parties who are related to it in some way). A letter of land recognition is essential to secure local community access to their own land. Secure land tenurial status will motivate the local community to invest (time and money) in order to enhance their livelihoods. Under uncertain individual rights and properties, incentives to invest in land and tree resources may be thwarted (Besley 1995 in Suyanto 1999).

Local land tenure dynamics in Bungo revolve around purchases and inheritance. Bungo local communities are mostly Moslems who originated from the Minangkabau culture and apply a halfmatrilineal inheritance system. In this system, there are two resources that can be inherited: harta berat (paddy rice fields, houses, jewelery) for the daughters; and harta ringan (dry land area, such as fallow (sesap and belukar) and agroforestry gardens) for the sons. During the inheritance process, customary leaders (ninik mamak) are the witnesses and other important village leaders are also invited to attend the inheritance process. Adnan and Yentirizal (2008) described how a local community has different schemes to gain private status of land: (i) open the forest or belukar with shifting cultivation; (ii) purchasing; (iii) inheritance; and (iv) a grant from relatives. For transmigrants, they can gain land by (a) purchasing land from a local community member; (b) renting; and (c) opening the forest with shifting cultivation.

Special cases such as the transmigration program can also influence land tenure dynamics in an area (Adnan and Yentirizal 2008). Government is sometimes willing to change the status of state land in order to support a transmigration program, which is what happened in 1989 (Ministerial Decree No. 720/KPTS-II/1989) with the PIR-Trans. The government, collaborating with PT Jamika Raya in a transmigration program, changed the status of 'production forest' to 'area for other uses'. In a transmigration area where land is becoming scarce because the population is increasing, a local community may change their communal property status to private property, as described by Otsuka 
et al (2001) in Sumatra. Otsuka et al. found that a customary land tenure institution had been evolving towards greater tenure security in response to increasing land scarcity. In this case, the local communities considered private property status to be more secure than communal property. Furthermore, in most cases, a local community will perceive state property differently from how the government perceives state property.

\subsubsection{Natural resources management regulations and environmental ethics}

In theory, biodiversity is the 'boundary object' (the entity that emerges on the interface of a sciencepolicy or knowledge-action interface) that could link local livelihoods with availability of natural resources. Both terrestrial and aquatic biodiversity play major roles in providing sources of local livelihoods and environmental services.

The local communities in Bungo district, particularly, had a high dependency on natural resources for their livelihoods and had developed a sustainable management system for natural resources through a 'learning by doing' process and through sharing experiences with other people in the same community or between communities. Kebun karet campur (rubber agroforests) was one way the Bungo local community managed their terrestrial natural resources while lubuk larangan (river fish pool) was an example of local community wisdom in managing aquatic natural resources. These natural resource management systems were inherited from generation to generation.

Basic, crucial information on natural resources management was mostly in the form of customary regulations. Each local community (bathin) in Bungo may have their own customary regulation depending on availability and status of natural resources. For example, the lubuk larangan (fish breeding site) management mostly occurred in upstream areas (such as Lubuk Beringin) rather than downstream (such as surrounding Danau village). Customary regulations for rubber agroforest and forest management were similar in all villages in Bungo district.

Local regulations affecting natural resources management mostly had direct links to forest management rather than rubber agroforests. Timber and non-timber forest product harvesting in customary forests are managed under customary regulations. In the rubber agroforests, customary regulations only dealt with land ownership. After forest was converted to rubber agroforest, its management would depend on the owner.

Moreover, there were also general customary rules that had been used by all the bathin in Bungo district. Those general customary rules (Table 3) were collected in the Bungo District Customary Manual (Buku Panduan Adat Kabupaten Bungo). The Customary Manual only used basic Malay terms with very limited explanations of their meaning. Therefore, to avoid misinterpretation, detailed explanations of each term need to be included that were understandable by all bathin in Bungo district (Pariyanto 2008).

Beside customary regulations, there were also regulations that were approved by the district government and applied in the local community. These government regulations were applied more intensively after 1979, when the village designation began, and have induced the involvement of outsiders in the bathin community. Compared to customary regulations, government regulations have stronger legal status. 
Table 3. Examples of general customary rules for natural resources management in Bungo

\begin{tabular}{|c|c|c|}
\hline \multirow{2}{*}{ Issues } & \multicolumn{2}{|l|}{ Customary rules } \\
\hline & Malay terms & Meaning \\
\hline Tenurial & $\begin{array}{l}\text { Tando kayu batakuk lopang, } \\
\text { tando kulik kaliki aka }\end{array}$ & $\begin{array}{l}\text { Property rights of land or trees must be clearly marked } \\
\text { in order to reduce future property rights conflict. For } \\
\text { example, pinang (betel) trees are usually planted to } \\
\text { mark the land boundary }\end{array}$ \\
\hline $\begin{array}{l}\text { Starting new } \\
\text { sesap (part of } \\
\text { shifting } \\
\text { cultivation) }\end{array}$ & Sompak, kompak, setumpak & $\begin{array}{l}\text { If you want to open a new area for agricultural } \\
\text { purposes, you have to do it in groups, don't do it by } \\
\text { yourself. If you do it yourself, social sanctions will be } \\
\text { applied to you by the customary leaders (ninik mamak). }\end{array}$ \\
\hline $\begin{array}{l}\text { Natural } \\
\text { resource } \\
\text { exploitation }\end{array}$ & $\begin{array}{l}\text { Umpang boleh disisip, kerap } \\
\text { boleh diganggu }\end{array}$ & $\begin{array}{l}\text { You need to explore the natural resources potency } \\
\text { before you exploit it, if the resource is in a good } \\
\text { condition you may exploit it, and restore/rehabilitate the } \\
\text { disruptions that were caused by the exploitation }\end{array}$ \\
\hline $\begin{array}{l}\text { Natural } \\
\text { resource } \\
\text { conservation }\end{array}$ & $\begin{array}{l}\text { Bak napuh diujung tanjuk, } \\
\text { ilang sikuk baganti sikuk, ilang } \\
\text { lapuk baganti ali }\end{array}$ & $\begin{array}{l}\text { Natural resources sustainability needs to be } \\
\text { maintained }\end{array}$ \\
\hline $\begin{array}{l}\text { Forest } \\
\text { conservation }\end{array}$ & $\begin{array}{l}\text { Kalo rapat boleh dijarangkan, } \\
\text { kalo jarang harus ditanam }\end{array}$ & $\begin{array}{l}\text { You may cut timber from a dense forest stand and you } \\
\text { have the obligation to replant it with trees to maintain } \\
\text { its level of tree density }\end{array}$ \\
\hline $\begin{array}{l}\text { Land } \\
\text { rehabilitation }\end{array}$ & Lapuk jua jalipung tumbuh & Critical land needs to be rehabilitated \\
\hline $\begin{array}{l}\text { Payment for } \\
\text { NRM in } \\
\text { communal } \\
\text { property }\end{array}$ & $\begin{array}{l}\text { Ka darek babungo kayu, ka } \\
\text { ayik babungo pasir }\end{array}$ & $\begin{array}{l}\text { NRM for commercial purposes will be charged } \\
\text { (pancung alas) to the village development fund }\end{array}$ \\
\hline Hunting wildlife & Tanah lombang, umput layu & $\begin{array}{l}\text { If you kill a wild animal for food you must share it with } \\
\text { other people in the village }\end{array}$ \\
\hline Fishing & $\begin{array}{l}\text { Menauh, nyukam, jalo, } \\
\text { nembak, najur, nagang, pukat } \\
\text { dan lukah }\end{array}$ & $\begin{array}{l}\text { Traditional methods for fishing in the river, without } \\
\text { poison and electricity }\end{array}$ \\
\hline
\end{tabular}

Source: customary regulations collected by Pariyanto (2008)

\subsubsection{Mechanisms for and attitudes toward enforcement}

Customary regulations are still respected and used by the local communities in Bungo, particularly to resolve internal village conflicts through the customary institution. Sanctions are applied to local members who don't abide by the rules. The sanctions are very flexible and are decided by the community. However, the importance of customary rules appears to be decreasing.

Customary institutions play a major role in natural resources management through consistent application of rules and sanctions. Customary institutions should work hand in hand with village governments. Village governments have a more direct link and access to information at the district government level than do customary institutions. Therefore, village governments are expected to be the communicator between the district government and customary institutions. But in reality, in some villages, the village government feels that they have more administrative authority than the customary institution and all administrative matters fall under the supervision and authorisation of 
the village government. Village systems and regulations have increasingly dominated local daily life and weakened respect for customary rules.

The authority to declare a peraturan desa is in the hands of the village government as one of the policy decision makers. In theory, a village regulation needs to be designed and agreed upon by all villagers. But, in reality, involving all villagers would take too much time, therefore the village government usually takes a shortcut and only asks the opinion of several village stakeholders in designing the regulation. This attitude has caused the decision-making process to become less than transparent and may encourage the elite to capture the village decision-making process. Therefore, if the village government wants to continue to take shortcuts in decision making, after designing the regulation they must socialise what they recommend to all community members before they make the final decision. If not, the community will not respect the decision or will become disadvantaged.

Taking the lessons from Baru Pelepat, Sungai Telang and Batu Kerbau (Adnan and Yentirizal 2008, Endah 2008), village leadership is essential to support the effective use of natural resource management. Baru Pelepat, Sungai Telang and Batu Kerbau local communities have learned to be more careful in electing their village leaders/governments because they lost tenurial rights over their own land owing to one decision made by their leaders. Corruption also has arisen where the village leaders are also the elites.

On the other hand, beside good leadership, respect and trust between village groups also needs to be maintained for an effective use of natural resources in the area. Collective action is effective in maintaining a normal level of trust and respect between village elements (Adnan and Yentirizal 2008, Siagian and Neldysavrino 2008). Chaniago (2008) observed that in Lubuk Beringin village, collective action groups were more effective in improving livelihoods via sustainable natural resources management when the formal village organisations were inactive. In transmigration areas, collective action involving the local community with the new-comers, reduces the potential for social conflict. Collective action activities may be different for men and women. Men are more interested in competition that could enhance their economic status, while women are more interested in the process of building social relations that could enhance collaboration between stakeholders.

Local community knowledge and organisational and technical skills need to be enhanced through training and other capacity-building activities in order to support the wise use of local natural resources.

\subsubsection{Sanctions}

The types of sanctions for anyone who disobeys a regulation in a village depend on the level of 'crime' and the type of regulation (for example, customary or village regulation). Village regulations may have different sanctions than customary regulations. Village regulations usually will refer to the national scheme for sanction determination, that is, reporting the crime to the police and letting a judge in a court decide the type of sanction. But in reality, owing to lack of knowledge and experience in reporting a crime to a formal court, local communities still prefer to process someone who has commited a crime based on steps that are informally regulated in the customary norms. In some cases, the local community will eventually report the crime to the formal court process if they are unable to solve the problem through their customary norms and sanctions.

Sanctions that are documented in the customary regulations are valid for anyone (local community, outsiders/external stakeholders) who are proved to have commited a crime in the customary area. 
Types of sanctions that are given vary based on the level of the crime. 'Soft' notification is usually given by customary leaders to people who are caught committing light crimes such as stealing fish from the village reservoir. People who are proved to have commited a heavy crime, such as illegal logging, need to pay (money or other material like goats, rice) to the village. The money is transferred to village cash-savings and used for village development (for example, building mosques, roads, schools).

The process to determine the type of sanction for each crime is initiated by reporting the crime to the customary leaders. The reporting can be done by an individual or a group of people who saw the crime. Based on the report, an investigation team is formed who collect proof and other related information. After enough evidence is collected then the investigation team proposes a meeting with the customary institution. Then, an open meeting is held, lead by the customary institution. The village government, village representative board, village leaders, the investigation team and the prime suspect are invited to attend the meeting. All the villagers are allowed to participate. The customary institution plays the role of judge and refers to principles that are documented in the customary and village regulations. A sanction, which is agreed by all participants, will be given to the person who was proven to have committed a crime in the village.

In the context of natural resources management, an example of how sanctions are applied in a local community in Bungo district can be seen in the Customary Forest (Ismail 2008) and the Lubuk Larangan cases (Sarma 2006, Permatasari 2008) in Baru Pelepat.

- Customary regulations for Hutan Adat (customary forest) in Baru Pelepat are now documented under village regulations (peraturan desa). One type of sanction that is documented in the customary regulations is a bungo, that is, interest percentage that needs to be paid to the village by the person who took non-timber forest products more than the quota allowed for a person. For instance, if there somebody took more than $10 \mathrm{~L}$ of honey from the forest then that person needed to pay bungo of $10 \%$ of the gross nett gain from harvesting the honey. For a heavy crime, such as illegal logging, the person must pay at least Rp 2500000 to the village.

- Lubuk larangan (fish reservoir) is normally harvested once some time from six to 24 months. If someone collected the fish outside of the designated harvest time, it would be considered as stealing, therefore a sanction would be applied. The sanction would be agreed via a meeting attended by the customary leaders and other elements in the local community. The sanction will be applied based on the level of crime:

(i) For light crimes, like stealing fish using traditional methods, then the customary leaders will first give a warning to to not make the same mistake again and the thief would need to pay a customary fine to the village, that is, 1 chicken, 1 gantang of rice (1 gantang equals $16 \mathrm{~kg}$ ), 2 kayu of white textile ( 1 kayu equals $2.5 \mathrm{~m}$ ).

(ii) If the thief is a recidivist, committing a second crime, or if a first-time thief committed a 'heavy' crime (like stealing fish using electricity or poison), then the customary leaders would ask the thief to pay to the village 1 goat, 20 gantang of rice, seasam segaram (ingredients to cook the goat), an amount of money (Rp 500 000), 2-4 kayu of textile. Also, if agreed by all the local community, the customary leader would report the matter to the police. 
(iii) The fish thief would also automatically experience a supranatural sanction.

Supranatural sanctions are given by religious or customary leaders on the first day of Lubuk Larangan. People who steal fish from Lubuk Larangan are warned that they will be sick and experience great pain: if they eat the fish they will have a stomach ache. The pain will stop if a treatment is given to the person by the leaders who gave the supranatural sanction. The treatment consists of reading Yasin (a statement from the Al-Quran) 40 times to the person and the person needs to drink water that was blessed by the religius leader. At the end of the treatment, the person bathes in the holy water. The advantage of the supranatural sanction is that it requires no labour to guard the natural resource.

As part of the process of rules enforcement, sanction application greatly influences the level of motivation to obey the rules. Proving whether somebody is guilty or not is becoming the main challenge in applying sanctions applicable to natural resources management and good leadership by the village leaders plays a major role (Ismail 2008). Another challenge is that natural resources are located across a very wide area with poor accessibility.

\subsubsection{Disincentives that interfere with sustainable management of natural resources}

Challenges in applying the sustainable use of natural resources management mainly comes from human factors. The capture of control by elites, high external threats and a lack of respect for, and access to, customary norms for the younger generation are types of disincentive that interfere with the sustainable use of natural resources. The external disincentive is mostly due to weak coordination between the local community and the district government.

(a) Elite capture. Elite capture can be encountered in all elements of a local community, either in the village government, customary institution or in any other village form of organisation. Critical and active participation of all village members in the decision-making process could reduce opportunities for elites to capture power. A study by Komarudin et al (2007) in Sungai Telang showed that village groups avoided elite capture in three ways. First, group members united and agreed on shared desires and risks. For example, they stuck to their commitment not to sell land to the oil palm company individually and refused to pay fees to the village head. Second, with regard to the village head who attempted to block access to a government grant, the villagers simply nagged him, complained to the subdistrict and eventually met directly with him. By building relations with outsiders and drawing attention to misconduct, villagers forced the elites concerned to stop their actions. Third, the villagers created a new group that excluded the elites who misused funds and also imposed more strict rules to constrain their own behavior.

Examples of types of elite capture in a local community:

- Elite capture of a customary institution: customary leaders who have poor respect for other people's opinions and consider other people have a lower social level. Endah (2008) showed that elite capture behaviour in the customary decision-making process caused decisions to become more subjective and did not provide equitable solutions. People who had close relations with the elites would benefit more from the decisionmaking process. The impact of elite capture of the decision-making process has been acknowledged by local communities for many years and even mentioned in the 
customary norms: tibo di mato dipiciangkan tibo di paruik dikampihkan means that there will be people or opinions that will not be counted in the decision-making process if an elite dominates. Elite captures of a customary institution will influence people's decisions to give very light or even no sanctions to their limbago (that is, a close relation between families in the Malay traditional system that often encourages nepotism) who committed a 'crime' (Helmi 2006). Local communities who respect customary institutions tend to accept the decisions made by elites in order to avoid horizontal conflict in their society. The behaviour of elites in customary institutions has discouraged and demotivated local communities from obeying customary and village regulations.

- Elite capture of a village government: village leaders who consider themselves to have more power and authority in all decisions related to village administrative matters. Sarma (2006) showed that an elite in a village government sometimes negotiated an agreement with a company without asking for the opinions of other villagers. In other cases, weak control over village government activities has encouraged corruption among elites.

(b) Lack of respect for, and access to, customary norms and rules by the younger generation. Most of the younger generations in the local communities tend to think that the customary norms and rules are too rigid to be applied in a dynamic social system while the old generations still consider that customary norms and rules are valid in any condition and time. Lack of facilities (such as documents, storytelling from elders to youth, involving younger people in customary meetings) for the younger generation to understand and learn about the customary norms and rules has encouraged a lack of respect by the younger generation. Decreasing interaction between the older and young generations could hinder the implementation of customary rules in the future.

(c) High level of external threats/pressures. Helmi (2006) stated that when a local community's respect for customary norms was decreasing, local people would be less likely to survive external threats and pressures. This has happened in Baru Pelepat. When a logging company entered the village and began logging, most of the local community imitated the company's behaviour and neglected their knowledge of, and respect for, their own customary norms and rules.

\subsubsection{Local conflict resolution mechanisms}

Conflicts that happen in a local community can be classified as horizontal and vertical types. Horizontal conflict is internal village conflict or conflict with other villages. Vertical conflict is conflict between the local community with the district government or other external stakeholders at a higher level. In most cases in Bungo district, land tenure is the most crucial natural resource management issue. Boundaries between villages and between gardens are the main issues in horizontal conflict while unclear or overlapping boundaries between state and communal forests is the main issue in vertical conflict.

During and after the village designation based on national regulation No. 5/1979, in some villages the boundaries were not clearly mapped. Up until the time of writing, there are still very few actions that are facilitated by the government in resolving village boundary conflicts. These conflicts will 
escalate if there are external stakeholders who are interested in natural resource management in the conflict area. Before 1979, the territory per village was defined in customary basic information agreed by both parties. Unfortunately, at that time there was no detailed mapping to complement the customary basic information.

Marzoni (2006) showed that the challenges in mediating horizontal conflicts were the different historical backgrounds of the villages, different perceptions and motivations to resolve the conflict and the level of participation from the district government. For villages with similar historical backgrounds, horizontal conflict resolution usually can be mediated by a general customary regulation agreed by both parties. For villages with different historical backgrounds, different perceptions between villages need to be calibrated via intensive meetings. Marzoni (2006) also mentioned that a participatory map agreed on by all parties would be an effective tool for articulating and mediating conflict.

\subsection{District or landscape level}

Compared to local communities, land-use planning is better documented at district government level. District government has become the bridge between local communities and national government decisions. In theory, land-use planning is be conducted from the bottom to the top, therefore, land-use planning documentation could be used as a tool to enhance local community participation in the decision-making process at district level. But in reality, budget constraints and shortage of time were cited as the main drivers that hindered the bottom-to-top process.

Bungo district was formed in 1999 from Bungo Tebo district, which was divided into two (that is, Bungo and Tebo districts) owing to the size of the area to be covered at district level. Since Bungo district was formed, from 2000 to 2006 the Bungo district government has twice revised its spatial planning. The first revision was made related to the segregation process from the Bungo Tebo district, the second revision to synchronise the district spatial planning with investor interest in oil palm plantations and coal mining (Irawan et al. 2008). The spatial planning revision process was conducted over a one-year program involving a consultant agency that worked with the district government's technical team. Local community involvement in in deciding the direction of the spatial planning revision was less compared to the role of the consultant.

Reflection on the issues that emerged at landscape level during the spatial planning revision can be used to improve district-level efficacy in natural resources management. Those issues, in particular, relate to

- how government views local tenure;

- pertinent regulations, enforcement procedures and effectiveness, existing sanctions and effectiveness;

- conflict resolution mechanisms; and

- any disincentive for sustainable management and any corruption, both of which may interfere with good management. 


\subsubsection{District-level participants' views on local tenure}

District government views on local tenure can be derived from observing the results of the district's spatial planning process. From the 2000-2005 spatial planning map (Figure 9), it is clear that the district government acknowledged the community agricultural land located in non-forest lands ('area for other purposes' or APL) and the communal forests that had been registered with the local government. Local community agricultural land (like agroforest, ladang, paddy rice field) or even settlements located in the state forest (protected forest, production forest or national park zone) have weak tenure in the eyes of the district government.

Under Indonesia's Basic Forestry Law, 'state forest' means a forest located on lands bearing no ownership, therefore the local community cannot own land in those zones and the government has the right to rezone as agricultural land. However, local communities mostly acknowledged those zones as their communal land and property regulated under customary law. Therefore, conflict between local communities and the district government or the private sector sometimes arose when the district government emphasised the delineation of a state forest area or when there was a forest concession company permitted by the government to harvest timber in the area.

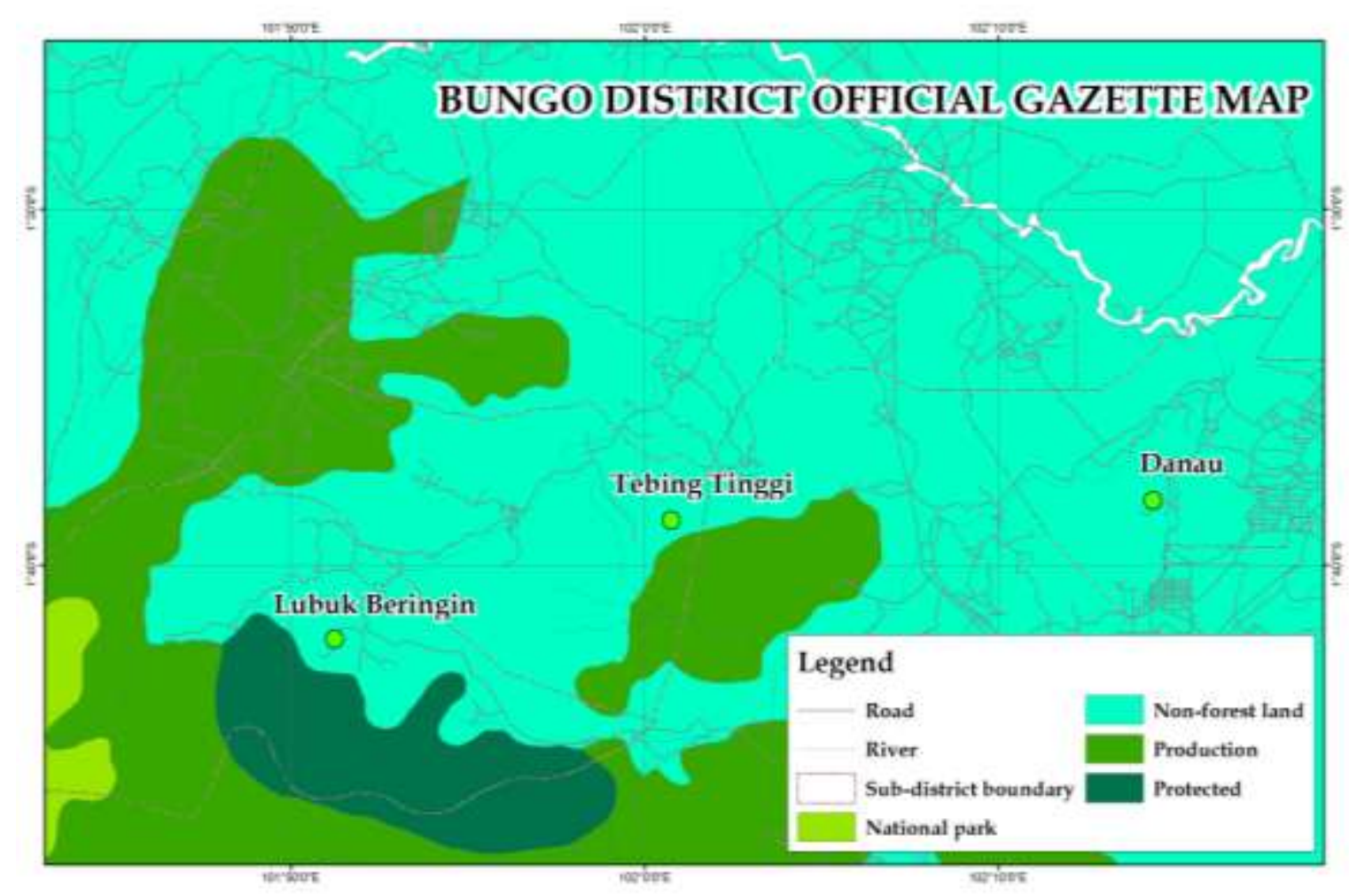

Source: World Agroforestry Centre Southeast Asia Program, Spatial Analysis Unit, 2008

Figure 9. Land-use types that are acknowledged in the Bungo district spatial plan 
Table 4. Typical land-use tenurial perceptions of stakeholders in Bungo district

\begin{tabular}{|c|c|c|c|c|}
\hline \multirow{2}{*}{$\begin{array}{l}\text { Land-use } \\
\text { type }\end{array}$} & \multirow[b]{2}{*}{ Neutral definition } & \multicolumn{3}{|c|}{ Type of tenurial perception of } \\
\hline & & $\begin{array}{l}\text { Local } \\
\text { communities }\end{array}$ & Governments & Private sector \\
\hline $\begin{array}{l}\text { Hutan } \\
\text { (forest) }\end{array}$ & $\begin{array}{l}\text { Virgin forest with very limited exploitation } \\
\text { activities }\end{array}$ & $\begin{array}{l}\text { Communal } \\
\text { property, open } \\
\text { access }\end{array}$ & $\begin{array}{l}\text { State property } \\
(\mathrm{HP}, \mathrm{HL}, \mathrm{NP})\end{array}$ & $\begin{array}{l}\text { State property } \\
(\mathrm{HP}, \mathrm{HL}, \mathrm{NP})\end{array}$ \\
\hline $\begin{array}{l}\text { Sesap } \\
\text { /ladang } \\
\text { (young } \\
\text { secondary } \\
\text { vegetation or } \\
\text { young } \\
\text { garden) }\end{array}$ & $\begin{array}{l}\text { Forest area that was opened for shifting } \\
\text { cultivation. Usually in the first } 1 \text {-to- } 3 \text { years } \\
\text { is planted with short-term agricultural } \\
\text { crops (e.g. chili, vegetables, cassava, } \\
\text { paddy) mixed with perennial plants (e.g. } \\
\text { rubber, fruit trees). The garden will be } \\
\text { abandoned after } 3 \text { years and only re- } \\
\text { visited when the perennial plants are } \\
\text { ready to harvest }\end{array}$ & $\begin{array}{l}\text { Private property } \\
\text { and inheritance } \\
\text { to sons }\end{array}$ & $\begin{array}{l}\text { Private } \\
\text { property (APL), } \\
\text { State property } \\
\text { (HP, HL, NP) }\end{array}$ & $\begin{array}{l}\text { Private property } \\
\text { (APL), State } \\
\text { property (HP, } \\
\text { HL, NP) }\end{array}$ \\
\hline $\begin{array}{l}\text { Belukar (old } \\
\text { secondary } \\
\text { vegetation) }\end{array}$ & $\begin{array}{l}\text { Old sesap that has been neglected for } \\
\text { more than } 5 \text { years with no clear } \\
\text { ownership. With the permission of } \\
\text { customary leaders, every community } \\
\text { member is allowed to manage the land for } \\
\text { non-perennial, agricultural crops with an } \\
\text { obligation to pay the land rent fee to the } \\
\text { village }\end{array}$ & $\begin{array}{l}\text { Communal } \\
\text { property }\end{array}$ & $\begin{array}{l}\text { Communal } \\
\text { property (APL), } \\
\text { State property } \\
\text { (HP, HL, NP) }\end{array}$ & $\begin{array}{l}\text { Communal } \\
\text { property (APL), } \\
\text { State property } \\
(\mathrm{HP}, \mathrm{HL}, \mathrm{NP})\end{array}$ \\
\hline $\begin{array}{l}\text { Kebun karet } \\
\text { campur } \\
\text { (rubber } \\
\text { agroforest) }\end{array}$ & $\begin{array}{l}\text { Sesap with rubber as its dominant } \\
\text { perennial tree ( } 700-1000 \text { seedlings } \\
\text { per ha) and managed extensively for } \\
\text { more than } 10 \text { years (when the first rubber } \\
\text { tapping activities usually start) }\end{array}$ & $\begin{array}{l}\text { Private property } \\
\text { and inheritance } \\
\text { to sons }\end{array}$ & $\begin{array}{l}\text { Private } \\
\text { property (APL), } \\
\text { State property } \\
(\mathrm{HP}, \mathrm{HL}, \mathrm{NP})\end{array}$ & $\begin{array}{l}\text { Private property } \\
\text { (APL), State } \\
\text { property (HP, } \\
\text { HL, NP) }\end{array}$ \\
\hline $\begin{array}{l}\text { Sawah } \\
\text { (paddy field) }\end{array}$ & $\begin{array}{l}\text { Areas that are intensively used to produce } \\
\text { rice, usually located near the centre of the } \\
\text { village, riverine areas and on relatively flat } \\
\text { land }\end{array}$ & $\begin{array}{l}\text { Private property } \\
\text { and inheritance } \\
\text { to daughters }\end{array}$ & $\begin{array}{l}\text { Private } \\
\text { property (APL) }\end{array}$ & $\begin{array}{l}\text { Private property } \\
\text { (APL) }\end{array}$ \\
\hline
\end{tabular}

During 2005-2006, the Bungo district government carried out a forest gazettement program. The objective was to clarify the Rantau Bayur Protected Forest, which is located in the southern part of Bungo and functions as a buffer zone for the Kerinci Seblat National Park, by reconstructing the boundaries of Sungai Telang village (35 km in length) (Hadi et al. 2008). The forestry and estate crop department in Bungo was mandated as the coordinator of this boundary reconstruction, based on a dictum from the head of Forest Planology, Forestry Department, No. SE.722/VII-KP/2005. The dictum stated that, except for the national park, the forest boundary reconstruction was the authority of the provincial and district governments (Hadi et al. 2008). The other team members in the reconstruction were the National Forest Gazettement Agency (Balai Pemantapan Kawasan Hutan or $\mathrm{BPKH})$, Jambi province and local communities that had interests along the reconstruction line. The desired outcome of the activity was enhanced stakeholders' awareness in supporting conflict resolutions in any forest delineation-local community tenure issue. 
During the reconstruction process, the team found at least five households had converted land in the protected forest into rubber gardens. Resolution of this matter was discussed through a meeting by the team with the head of the village, the head of the village representatives board (BPD) and other village leaders. In the meeting, it was agreed that the local community that had converted the protected forest into rubber garden would be allowed to maintain their garden until it become unproductive, while at the same time the local community was not allowed to expand rubber gardens in the protected forest. The local community was also expected to plant and rehabilitate the critical areas with forest tree species with the purpose of avoiding landslides. Unfortunately, the reconstruction was constrained by a limited budget, therefore it was only conducted once during 2005-2006 in only one village. Meanwhile, there were more than 10 villages in the area that had forest and village boundary conflicts.

In reality, the district government had not considered that villages' spatial planning could be used as the basis for designing the district's spatial planning. In this context, bureaucratic and funding constraints should not be seen as a barrier in synergising the village and district spatial planning. At district level, interaction needs to be improved to enhance the role of village spatial planning as the basis for designing the district's spatial planning (Marzoni 2008).

\subsubsection{Pertinent regulations, enforcement procedures and sanction effectiveness}

Natural resources management at the district level was regulated in district-level laws (peraturan daerah or perda). Based on the Indonesian judicial system, as regulated in Law No. 10/2004, the regional-level governments (district and province) have the authority to form perda while village governments are able to form village regulations (peraturan desa or perdes). In this system, no law of a lower rank can be contradictory of a law of higher rank. In perda, local regional decisions are voted on by the regional representatives board (DPRD) and legalised by the governor/bupati/walikota. For perdes, the decisions are voted on by the village representatives board (BPD) and legalised by the head of the village.

Since decentralisation in 2000-2003, there were 17 perda (district-level regulation) in Bungo district that related to natural resources management, that is, five to mining (gold, coal and sand), four to logging and one for plantation forests (Suherman and Taher 2008). Perdes that relate to natural resources management in the district are still minimal. Baru Pelepat village is perhaps the most advanced village in Bungo district in terms of forming perdes, owing to the intervention of $\mathrm{ACM}^{3}$, assisting villagers to form perdes to manage natural resources in the village.

During the transition period of 1999-2000, after the New Order era ended in 1998, the regional governments were given more authority in managing natural resources, particularly in relation to logging concessions to the private sector for small-scale forest management and harvesting. But in 2002, the regional governments' authority over forest management was declared invalid by a law of the Ministry of Forestry. Regional governments no longer had the authority to issue their own regulations but instead had the obligation to assist the implementation of regulations issued by the national government. Based on the Ministry of Forestry decree No.382/kpts-II/2004, the national

\footnotetext{
${ }^{3}$ ACM = adaptive collaborative management. ACM was a major program of the Center for International Forestry Research from 1998 until the mid-2000s. It evolved out of two previous projects: Assessing Sustainable Forest Management: A Test of Criteria and Indicators, led by Ravi Prabhu; and Local Livelihoods, Community Forests and Devolution, led by Lini Wollenberg.
} 
government authorised regional governments to issue small-scale logging concessions (such as Izin Pemanfaatan Kayu Rakyat or IPKR) for non-forest state land. IPKR permits were to be granted to cooperatives, farmers' groups or foundations in areas outside state forest, that is, 100 ha of NonForestry Use Areas on privately owned land.

The Ministry of Forestry decree No.382/kpts-II/2004, made it clear that the owner of the logging concession must practise sustainable forest management. But in implementation, however, the concession owners only concentrated on harvesting. In some areas such as Baru Pelepat village, the concession holder operated not only in the designated APL but also the state forest. This kind of 'disobedience' was sometimes mis-monitored by the government. On the other hand, local communities were well able to monitor such disobedience. Owing to weak law enforcement in the area, sanctions were seldom applied to the private sector actors who did not obey the rules. Generally, when there is a lack of law enforcement in an area where the rights of the stakeholders are also unclear, conflict becomes a logical consequence.

\subsubsection{Conflict resolution mechanisms}

At district level, conflicts may happen within government agencies (internal conflict) and between government agencies with other stakeholders (external conflict). The external conflict can be divided into horizontal and vertical conflict. Horizontal conflict is with other stakeholders at the same level (such as with a logging company), while vertical conflict is with local communities and the provincial or national governments.

Internal conflict usually happened owing to overlapping authorities and programs between departments in the district government. Weak coordination between departments is usually the cause of internal conflict. BAPPEDA (the district planning board) plays a major role in maintaining good coordination between departments. Resolution mechanisms for internal conflict are usually dependent on the leadership of the bupati and the quality of human resources at the BAPPEDA office.

External conflict was usually a result of lack of transparency among stakeholders. Compared to internal conflict, external conflict had a bigger impact on the sustainability of natural resource management. Resolution mechanisms for external conflict were dependent on the transparency of dialogue and the level of participation of the various stakeholders. Bupati play major roles in ensuring the efficacy of both (external and internal) conflict resolution at district level.

Opaque activities at district level mostly occurred when issuing permissions to manage natural resources to the private sector without involving the community in the decision-making process. Yasmi (2008) analysed this process in Baru Pelepat village in Bungo where there was conflict between the community and a timber concession held by PT Merangin Karya Sejati (MKS). The community felt that they had customary rights over the land that was logged by MKS, while MKS felt that they had the right to conduct legal logging as the district government had formally given permission to MKS. MKS had maps that were signed by the bupati and the district forestry department that showed the logging area while the community had no proof of their customary rights. Under these circumstances, the community was in a weak position and there was lack of support and intervention from the district government in recognition of local tenurial rights.

Vertical conflict also often occurred between the district and provincial or even national governments, particularly over the issue of authorisation of management of natural resources and 
delineation of forest boundaries. Hence, Sudirman et al (2005) recommended that the national government should work with regional governments (district and provincial) to establish a framework for developing district regulations that were capable of meeting local needs in line with commonly accepted national standards. To complement that, the district government should conduct a judicial review, overview and evaluation of local forestry regulations, involving a wide range of local stakeholders. Public participation should be improved in the following ways.

- Develop a regulation that will standardise and legalise mechanisms for public participation. It can be used to guide local government in making local laws and regulations that comply with good governance principles. It would also strengthen public trust and compliance.

- Provide sufficient human and financial resources. It is important that the regional government supports the 'public participation fund' (Dana Partisipasi Masyarakat or DPM) from the regional budget, based on the planned local legislation programs.

\subsubsection{Disincentives for sustainable management and possible corruption problems that may interfere with good management}

Actual land allocation frequently strays from the spatial plan. Allocation is sometimes subject to elite capture by district officials who authorise developments that benefit themselves and are inconsistent with the spatial plan. Growing populations in need of land, increased investment opportunities potentially important for district revenues and greater district responsibilities in governance plague district governments throughout the country.

Suherman and Taher (2008) showed that more authority given to a district government in issuing permissions to manage natural resources had been used by elites at district level to gain more profit. In Batu Kerbau village, for example, CV Beringin Hijau used the IPHH (a type of small-scale logging concession) to legalise timber that was harvested in other areas that were not part of the concession, operating a kind of 'timber laundering'.

\subsection{Conflict management at national level}

Based on an analysis conducted by the United States Agency for International Development's (USAID) Natural Resource Management: Environmental Policy and Institutional Strengthening (NRM-EPIQ) program in 2002 of Indonesia's National Basic Law on natural resource management, conflicts related to issues such as
a. ambiguous property rights, customary law, role of the state;
b. inconsistencies in the Constitution (Articles 18 and 33);
c. conflicts in purpose, ownership, jurisdiction, accountability;
d. existing laws too sectoral, not coordinated, legal gaps; and
e. weak national institutions and local capabilities.

The study found that resolutions of these types of conflict could be mediated through
a. supporting national forums to formulate coordinated action plans;
b. customary people's congresses; 
c. holding natural resource management conferences;

d. technical assistance for specific initiatives and NGO coalitions;

e. a task force on natural resource management basic law and constitutional amendment; and

f. forming a working group on agrarian reform (TAP MPR No. 9/2002).

Other lessons from the NRM-EPIQ study were that intervention in mediating Indonesia's natural resources conflicts at national level needed to considered matters such as
a. facilitating dialogue among all parties on the scope and need for action;
b. building confidence through simple activities and active cooperation;
c. facilitating trust for more formal institutional cooperation;
d. developing conflict management mechanisms and institutions;
e. channelling conflict into discussion and arbitration;
f. granting an institutional arbitrator the authority to make binding decisions;
g. seeking to combine rules and policies with economic incentives; and
h. transparent, regular monitoring and feedback on activities being essential for development of institutional legitimacy.




\section{Links between governing bodies at local and district level}

Links between governing bodies at local and district level can be seen in how spatial planning at district level was designed and implemented. In most districts in Indonesia, the spatial planning process still follows the top-down approach, though the national regulation states that the process needs to be drawn from village up to district and provincial levels.

Synchronising village spatial planning with district spatial planning would provide an opportunity for local people to be prioritised in the district's annual development program, hence providing an effective development process. Based on national regulation No.25/2004, as part of annual planning for development each region (village, sub-district and district) should create its own development plan through participatory meetings. However, based on the analysis by Limberg et al. (2006) of the spatial planning process at community level in Kabupaten Malinau, East Kalimantan, synchronising village and district spatial planning faced a number of challenges:

- lack of data, maps and experience at village level;

- the time limit of one year in which BAPPEDA had to finish the work; and

- difficulties of compliance at district level, that is, in scaling up the village-level issues to district level.

These challenges were also experienced in Bungo district.

\subsection{Issues, conflicts and collaboration between the two levels of governance}

In Bungo, the transmigration program can be used to analyse the interaction between villages and the district government. Transmigration areas (such as Kuamang Kuning) are being used as sources of information by people from non-transmigration areas. Other types of interaction can also be observed in the implementation of district government programs, particularly those related to the agriculture and forestry sectors. Collaboration between village and district governments is stimulated by government programs that are offered to the villages. Programs like the Special Area

Development Project (Proyek Pengembangan Wilayah Khusus or P2WK), which provides grants for development of estate crops in specific areas; the National Program (Program Nasional or Prona) on land certification and; Productive Business Assistance (Bantuan Usaha Produktif) for supporting small-scale agribusinesses are usually offered to groups rather than to individuals. Most of the time, economic development is the main goal of the program any focus on conservation or environmental development is very limited. 


\section{Box 1. Transmigration program}

The objective of the transmigration program in Indonesia is to alleviate poverty by providing land and new opportunities to generate income for poor, landless settlers. Adhiati et al. (2001) described the transmigration program in Indonesia, at various times, as divided into different schemes.

- Transmigrasi Swakarsa Pengembangan Desa or Transabangdep (Village Potential Development Transmigration Scheme): local authorities in destination regions request groups of transmigrants to support the development of their regions and villages.

- Perkebunan Inti Rakyat Transmigrasi or PIR-Trans or NES (Nucleus Estate Smallholders Transmigration Scheme): groups of transmigrants are resettled and work on cash-crop plantations.

- Kehutanan and Hutan Tanaman Industri or HTI (Forestry and Industrial Plantation Forestry): similar to PIR-trans but the transmigrants are engaged in forestry/timber plantation projects;

- Ternak (Livestock); Nelayan/Tambak (Fishery); Jasa/Industri (Public Service and Industry) schemes: each refers to the main field of work in the destination transmigration areas.

In Bungo, PIR-Trans (NES-transmigration) with oil palm and rubber were the common transmigration types in the area since 1983 (Table 5). Levang (1997) explained that the NES scheme was first linked with tree-crop development in a transmigration program during the third Five-Year Development Plan (REPELITA III) 1979-1984 at a time when the government was applying for new World Bank loans. From the early 1980s, considerable World Bank and Asian Development Bank (ADB) funds were made available to expand tree-crop plantations using NES schemes. NES projects were concerned with new area development on the outer islands and involved clearing forested land and establishing transmigration sites. Up to $80 \%$ of the participants in NES projects were transmigrants, who were sent to newly cleared areas in remote regions in Kalimantan, Sumatra, Riau and West Papua. They were provided with land, houses and community facilities and received agricultural support and extension services, mainly to grow tree crops such as rubber and oil palm for export. 
Table 5. Transmigration programs in Bungo district

\begin{tabular}{|c|c|c|c|c|}
\hline Year & $\begin{array}{l}\text { Location } \\
\text { (total area) }\end{array}$ & \# HH & $\begin{array}{l}\text { Agricultural } \\
\text { commodity }\end{array}$ & Transmigration type \\
\hline 1983 & $\begin{array}{l}\text { Kuamang } \\
\text { Kuning }\end{array}$ & $\mathrm{N} / \mathrm{A}$ & $\begin{array}{l}\text { Initially food crops } \\
\text { around village; oil } \\
\text { palm and rubber } \\
\text { became dominant } \\
\text { income source }\end{array}$ & PIR-Trans \\
\hline $\begin{array}{l}1997 \\
- \\
1998\end{array}$ & Baru Pelepat & 150 & Oil palm, rubber & $\begin{array}{l}\text { Community-owned land was exchanged } \\
\text { for tree crop plantations under the } \\
\text { P4HDR scheme } \\
\text { (Proyek Pelaksanaan Program } \\
\text { Pemukiman Perambah Hutan melalui } \\
\text { Dana Reboisasi P4HDR = 'replace slash } \\
\text { and burn via reforestation funds') }\end{array}$ \\
\hline 2004 & $\begin{array}{l}\text { Sungai } \\
\text { Telang } \\
\text { (1041 ha) }\end{array}$ & $\begin{array}{l}275(138 \\
\text { locals } \\
\text { and } 137 \\
\text { Javanes } \\
\text { e) }\end{array}$ & Oil palm & $\begin{array}{l}\text { Communitry-owned land was replaced } \\
\text { by oil [palm plantations; previous land } \\
\text { use: sesap, rubber agroforests, belukar }\end{array}$ \\
\hline 2006 & $\begin{array}{l}\text { Rantau } \\
\text { Pandan }\end{array}$ & & Oil palm & \\
\hline
\end{tabular}

NES schemes have meant that investors (private sector and state-owned companies) have been able to penetrate new areas of Indonesia's rainforests with government backing and with the financial support of the ADB and World Bank. The link with the transmigration program ensured a ready supply of cheap labour both to produce raw materials and process them. Most smallholder projects are in Riau, North Sumatra, Jambi and West Kalimantan. After the launch of NES, plantations rapidly expanded under the PIR-trans (NES transmigration) program (1986-1994) and the Members Primary Credit Union (Koperasi Kredit Primer Anggota or KKPA) scheme (1995-1998).

Failures in the transmigration program were identified by Fahmi Idris (Minister of Transmigration):

- the location did not meet the 2C (Clear and Clean) and 4L (Layak huni, Layak usaha, Layak berkembang dan Layak lingkungan/satisfactory for habitation, satisfactory for business, satisfactory for development and satisfactory for the environment) concepts;

- incompetent transmigrants; and

- poor local community empowerment.

Other studies mentioned that transmigration did not address the local community's aspirations (Elmhirst 2002).

Like other transmigration projects, NES schemes have caused serious environmental, social and economic problems. In many cases, transmigrants found themselves worse off than before. Their tree-crop operations and futures were insecure and wholly dependent on the nucleus estate and world commodity prices. They also faced problems with land entitlement, corruption and malpractice and difficulties in paying their loans. Environmental impacts were regarded as minor and socioeconomic impacts have been downplayed, while NES projects (especially oil palm) have been 
regarded as successful in changing industry policies and structure, increasing crop production and economic returns (White 2005; Zen et al. 2006).

In September 1998, the Studi Sosial Ekonomi Yayasan Gita Buana (Gita Buana Foundation Socioeconomic Studies) and the European Union working together on the Forest Inventory Monitoring Project predicted that village areas in the buffer zone of the Kerinci Seblat National Park were vulnerable to conversion to estate-crop plantations (industrial forest plantations, rubber, oil palm) or transmigration area. The prediction was realised during 2007-2008, when most of the villages in the upstream area (buffer zone of Kerinci Seblat National Park) in Bungo district were converted into PIR-trans with oil palm as the main commodity. Lubuk Beringin village was the only village in Bungo's upstream that has not given its land to be converted to a transmigration area or plantations.

Interestingly, despite the vast effect on the environment and local livelihoods, the transmigration program does not clearly appear in the district development plan (2006-2011). The revised spatial plan has been approved and implemented since 2006, detailing five years of activities as noted in the Mid-term District Development Plan (Rencana Pembangunan Jangka Menengah or RPJM Kabupaten Bungo). In the RPJM, indicators to measure the successful of development activities in the five-year period are:

- improved community welfare and district revenue;

- improved agricultural productivity; and

- improved infrastructure.

The proportion of conservation or environmental development activities in the RPJM is very limited and focuses mostly on decreasing water pollution owing to gold and coal mining.

\subsection{Communication patterns and trust between the two levels}

Communication patterns between the villages and district governments can be observed starkly when a village wants to include their area in a transmigration scheme. For instance, the Baru Pelepat villagers decided to propose their village, with the objective of improving local livelihoods. After presenting their proposal three times, the district government approved the Baru Pelepat transmigration scheme at the end of 1993, but it was not implemented until 1997 because the district government planned to establish coal mining in Desa Sungai Beringin and transmigration was given to that village (Adnan and Yentirizal 2008).

Ultimately, the Baru Pelepat community did not meet their expectations of improving their livelihoods. Problems occurred during the implementation of program. There was no awareness in the district government that the program could be used to support local community livelihoods. There was a small attempt from the District Transmigration Department to implement the Lahan Usaha 1 and 2 (business land) aspects of the program. Disnakertrans distributed rubber seedlings to the transmigrants but there was no training in how they should plant the seedlings; also the seedlings were of very poor quality. The problems in the Baru Pelepat transmigration area decreased local community trust in the district government.

However, Feintrenie and Levang (2011) observed in a perception survey conducted in 2009 in 12 villages of the district, a rather positive perception of the various levels of authorities by the 
population of Bungo. Villagers also perceived themselves as actively participating to political decision making, thanks to their right of direct election of their representatives. Villagers considered themselves as better-off than in the past - generally referring to the era of Suharto - whereas other stakeholders surveyed looked at the improvement still to be made and express less positive opinions (Feintrenie and Levang 2011).

\subsection{Opportunities for improvement in the relationship}

Building trust needs to be addressed to improve the relationship between the two governing bodies. For example, Siagian and Neldysavrino (2008) concluded that opportunities to improve local communities land tenure security could be found through collective action, particularly because most the government programs are more accessible to groups than individuals. It is also more efficient for the district government to monitor groups rather than individuals.

Generally in Indonesia, human population growth is the main challenge in integrating conservation and development in natural resource management. As the human population grows rapidly, issues of land accessibility appear and lead to land acquisition and security conflicts. Various stakeholders perceive legal claims over land differently and these different claims often bring conflict (either vertical or horizontal) about who has the right to manage the resources. Increasing land scarcity not only implies land-cover changes but also with social norms, regulations and property rights. Hence, developing participatory spatial planning and monitoring must be a priority for various stakeholders in managing their natural resources. 


\section{References}

Adhiati M, Adriana S, Bobsien A, eds. 2001. Indonesia's transmigration programme: an update. Hallbankgate, UK: Down to Earth. Available from http://dte.gn.apc.org/ctrans.htm

Adnan H, Yentirizal N (2007) Blessing or misfortune? Locals, transmigrants and collective action. CIFOR Governance Brief June:1-11.

Adnan H, Yentirizal. 2008. Adaptasi kelembagaan dan aksi kolektif masyarakat terhadap program transmigrasi. In: Adnan H, Tadjudin D, Yuliani L, Komarudin H, Lopulalan D, Siagian Y, Munggoro D, eds. 2008. Belajar Dari Bungo: Mengelola Sumberdaya Alam di Era Desentralisasi. Bogor, Indonesia: Center for International Forestry Research.

Akiefnawati R, Villamor GB, Zulfikar F, Budisetiawan I, Mulyoutami E, Ayat A, van Noordwijk M. 2010. Stewardship agreement to reduce emissions from deforestation and degradation (REDD): Lubuk Beringin's hutan desa as the first village forest in Indonesia. Working Paper 102. Bogor, Indonesia: World Agroforestry Centre (ICRAF) Southeast Asia Program.

Akiefnawati R, Budisetiawan I. 2010. Forum diskusi multipihak dan forest governance learning group Bungo. Kiprah Agroforestri 1. Bogor, Indonesia: World Agroforestry Centre (ICRAF) Southeast Asia Program.

Bustanul A. 2005. Institutional perspectives of lifescape co-management: lessons learned from RUPES sites in Sumatra, Indonesia. In: Murdiyarso D, Herawati H. Proceedings of workshop on carbon sequestration and sustainable livelihoods. Bogor, Indonesia: Center for International Forestry Research.

Chaniago D. 2008. Potensi pengembangan mekanisme imbal jasa lingkungan wanatani karet di desa Lubuk Beringin. In: Adnan H, Tadjudin D, Yuliani L, Komarudin H, Lopulalan D, Siagian Y, Munggoro D, eds. 2008. Belajar Dari Bungo: Mengelola Sumberdaya Alam di Era Desentralisasi. Bogor, Indonesia: Center for International Forestry Research.

Colfer CPJ. 2005. The complex forest: communities, uncertainty, and adaptive collaborative management. Washington, DC: Resources for the Future; Center for International Forestry Research.

de Vries WD, Sutarti N. 2006. Gender equity: revealing the reality for the women of Jambi. CIFOR Governance Briefs 29. Bogor, Indonesia: Center for International Forestry Research.

Ekadinata A, Vincent G. 2008. Dinamika Tutupan Lahan Kabupaten Bungo, Jambi. In: Adnan H, Tadjudin D, Yuliani L, Komarudin H, Lopulalan D, Siagian Y, Munggoro D, eds. 2008. Belajar Dari Bungo: Mengelola Sumberdaya Alam di Era Desentralisasi. Bogor, Indonesia: Center for International Forestry Research. 
Elmhirst RJ. 2002. Resource struggles and the politics of place in North Lampung, Indonesia. Singapore Journal of Tropical Geography 22: 284-306.

Endah RDDR. 2008. Hutan Adat Batu Kerbau: Sisa-sisa Kearifan Lokal. In: Adnan H, Tadjudin D, Yuliani L, Komarudin H, Lopulalan D, Siagian Y, Munggoro D, eds. 2008. Belajar Dari Bungo: Mengelola Sumberdaya Alam di Era Desentralisasi. Bogor, Indonesia: Center for International Forestry Research.

Feintrenie L, Chong WK, Levang P. 2010. Why do farmers prefer oil palm? Lessons learnt from Bungo district, Indonesia. Small-Scale Forestry 9 (3):379-396.

Feintrenie L, Martini E. 2010. Role of the district government in directing landscape dynamics and people's futures: lessons learnt from Bungo district in Jambi province. In: Colfer CJP, Pfund J-L, eds. Collaborative governance of forested landscapes. London: Earthscan.

Feintrenie L, Levang P. 2011. Local voices call for economic development over forest conservation: trade-offs and policy in Bungo, Sumatra. Forests, trees and livelihoods 20 (1). In press.

Fisher RJ, Prabhu R, McDougall C, eds. 2007. Adaptive collaborative management of community forests in Asia: Experiences from Nepal, Indonesia and the Philippines. Bogor, Indonesia: Center for International Forestry Research.

Guijt I, ed. 2007. Negotiated Learning: Collaborative monitoring in forest resource management. Washington, DC: Resources for the Future.

Guillaud D. 1999. L'hévéaculture paysanne dans la région de Jambi (Sumatra). Autrepart/Variations 11:115-135.

Hadi M. 2006. Membuka pintu pemerintah. In: Yuliani L, Tadjudin D, Indriatmoko Y, Munggoro D, Gaban F, Maulana F, Adnan H, eds. 2006. Kehutanan Multipihak: Langkah Menuju Perubahan. Bogor, Indonesia: Center for International Forestry Research.

Hadi M, Komarudin H, Schagen M. 2008. Kebijakan kehutanan, aksi kolektif dan hak properti: sebuah pelajaran dari Bungo. In: Adnan H, Tadjudin D, Yuliani L, Komarudin H, Lopulalan D, Siagian Y, Munggoro D, eds. 2008. Belajar Dari Bungo: Mengelola Sumberdaya Alam di Era Desentralisasi. Bogor, Indonesia: Center for International Forestry Research.

Hasan U, Irawan D, Komarudin H. 2008. Rio: Modal sosial sistem pemerintah desa. In: Adnan H, Tadjudin D, Yuliani L, Komarudin H, Lopulalan D, Siagian Y, Munggoro D, eds. 2008. Belajar Dari Bungo: Mengelola Sumberdaya Alam di Era Desentralisasi. Bogor, Indonesia: Center for International Forestry Research. 
Helmi. 2006. Dari Adat ke Peraturan Daerah. In: Yuliani L, Tadjudin D, Indriatmoko Y, Munggoro D, Gaban F, Maulana F, Adnan H, eds. 2006. Kehutanan Multipihak: Langkah Menuju Perubahan. Bogor, Indonesia: Center for International Forestry Research.

Indriatmoko Y, Yuliani L, Tarigan Y, Gaban F, Maulana F, Munggoro D, Lopulalan D, Adnan H, eds. 2007. Dari Desa ke Desa: Dinamika Gender dan Pengeloalaan Kekayaan Alam. Bogor, Indonesia: Center for International Forestry Research.

Irawan D, Hasan U, Komarudin H. 2008. Penataan ruang untuk memperkuat hak properti masyarakat. In: Adnan H, Tadjudin D, Yuliani L, Komarudin H, Lopulalan D, Siagian Y, Munggoro D, eds. 2008. Belajar Dari Bungo: Mengelola Sumberdaya Alam di Era Desentralisasi. Bogor, Indonesia: Center for International Forestry Research.

Ismail D. 2008. Jalan panjang partisipasi: proses dan pembelajaran dalam penyusunan peraturan desa secara partisipatif. In: Adnan H, Tadjudin D, Yuliani L, Komarudin H, Lopulalan D, Siagian Y, Munggoro D, eds. 2008. Belajar Dari Bungo: Mengelola Sumberdaya Alam di Era Desentralisasi. Bogor, Indonesia: Center for International Forestry Research.

Joshi L, ed. 2007. Bungo site profile. Bogor, Indonesia: World Agroforestry Centre (ICRAF) Southeast Asia Program.

Joshi L, Wibawa G, Beukema HJ, Williams SE, van Noordwijk M. 2003. Technological change and biodiversity in the rubber agroecosystem. In: Vandermeer JH, ed. Tropical Agroecosystems: New Directions for Research. Boca Raton, USA: CRC Press. p. 133157.

[KKI-WARSI] Komunitas Konservasi Indonesia-Warung Konservasi. 2009. Lubuk Beringin akan jadi kawasan Hutan Desa yang pertama di Indonesia. Jambi, Indonesia: KKIWARSI. Available from http://www.warsi.or.id/News/2009/News_200901_HutanDesa.asp?year=2009\&file=News _200901_HutanDesa.asp

Komarudin H, Yuliana L, Siagian Y, Colfer CJP, Neldysavrino, Yentirizal, Syamsuddin, Irawan D. 2007. Collective action to secure property rights for the poor: a case study in Jambi Province, Indonesia. Washington, DC: International Food Policy Research Institute.

Kuncoro SA, van Noordwijk M, Martini E, Saipothong P, Areskoug V, Ekadinata A, O'Connor T. 2006. Rapid Agrobiodiversity Appraisal (RABA) in the context of environmental service rewards: protocols for data collection and case studies in rubber agroforest in Bungo district, Jambi, Indonesia and fragmented forest in north Thailand. Bogor, Indonesia: World Agroforestry Centre (ICRAF) Southeast Asia Program. 
Kusumanto T, Yuliani L, Macoun P, Indriatmoko Y, Adnan H. 2006. Belajar Beradaptasi: Bersama-sama Mengelola Hutan di Indonesia. Bogor, Indonesia: Center for International Forestry Research.

Kusumanto T. 2008. Kolaborasi untuk kelestarian hutan dan kesejahteraan masyarakat. In: Adnan H, Tadjudin D, Yuliani L, Komarudin H, Lopulalan D, Siagian Y, Munggoro D, eds. 2008. Belajar Dari Bungo: Mengelola Sumberdaya Alam di Era Desentralisasi. Bogor, Indonesia: Center for International Forestry Research.

Levang P. 1997. La terre d'en face: la transmigration en Indonésie. Montpellier, France: ORSTOM.

Limberg G, Iwan R, Wollenberg E, Moeliono M. 2006. Bagaimana masyarakat dapat dilibatkan dalam perencanaan tata ruang kabupaten? Pengalaman dari Kabupaten Malinau, Kalimantan Timur. CIFOR Governance Briefs 16b. Bogor, Indonesia: Center for International Forestry Research.

Locher-Scholten E. 1994. Sumatraans sultanaat en koloniale staat: De relatie DjambiBatavia (1830-1907) en het Nederlandse imperialisme. Leiden, Netherlands: KLTV Uitgeverij. (Sumatran sultanate and the colonial state: Jambi and the rise of Dutch imperialism 1830-1907. New York: Cornell University Southeast Asia Program.)

Locher-Scholten E. 2009. Dutch expansion in the Indonesian archipelago around 1900 and the imperialism debate. Journal of Southeast Asian Studies 25: 91-111.

Marzoni. 2006. Negosiasi batas wilayah desa. In: Yuliani L, Tadjudin D, Indriatmoko Y, Munggoro D, Gaban F, Maulana F, Adnan H, eds. 2006. Kehutanan Multipihak: Langkah Menuju Perubahan. Bogor, Indonesia: Center for International Forestry Research.

Marzoni. 2008. Menata ruang desa: jalan menuju komunikasi dan kolaborasi. In: Adnan H, Tadjudin D, Yuliani L, Komarudin H, Lopulalan D, Siagian Y, Munggoro D, eds. 2008. Belajar Dari Bungo: Mengelola Sumberdaya Alam di Era Desentralisasi. Bogor, Indonesia: Center for International Forestry Research.

Michon G. 2005. Domesticating forests: how farmers manage forest resources. Bogor, Indonesia. Jakarta: International Relief and Development; Center for International Forestry Research; World Agroforestry Centre (ICRAF) Southeast Asia Program.

Miyamoto M. 2006a. Forest conversion to rubber around Sumatran villages in Indonesia: Comparing the impacts of road construction, transmigration projects and population. Forest Policy and Economics 9: 1-12.

Miyamoto M. 2006b. The relationship between forest conversion and inequality of land ownership, and the factors responsible for increasing the inequality in Sumatran rubber villages. Journal of the Japanese Forest Society 88: 79-86. 
Miyamoto M. 2007. Road construction and population effects on forest conversion in rubber villages in Sumatra, Indonesia. In: Dubé YC, Schmithüsen F, eds. Cross-sectoral policy developments in Forestry. Rome: Food and Agriculture Organisation; CAB International.

Murdiyarso D, van Noordwijk M, Wasrin UR, Tomich TP, Gillison AN. 2002. Environmental benefits and sustainable land-use options in the Jambi transect, Sumatra, Indonesia. Journal of Vegetation Science 13: 429-438.

[NRM-EPIQ USAID] United States Agency for International Development's Natural Resources Management Environmental Policy and Institutional Strengthening Project. 2002. Conflict management and natural resources management in Indonesia NRM-EPIQ's approaches and achievements in Indonesia's democratization and decentralization transition. Presentation. Jakarta: NRM-EQIP Group. Available from http://www.rmportal.net/library/content/tools/environmental-policy-and-institutionalstrengthening-epiq-iqc/epiq-environmental-policy-and-institutional-strengthening-cd-vol1/epiq-cd-1-tech-area-dissemination-of-policy-knowledge-environmentalcommunication/conflict-management-and-natural-resources-management-in-indonesianrm-epiq2019s-approaches-achievements-in-indonesia2019s-democratizationdecentralization-transition/view?searchterm=Indonesia\%20NRMP\%20II.

Nurrochmat DR. 2005. The impacts or regional autonomy on political dynamics, socioeconomics and forest degradation: case of Jambi, Indonesia. Gottingen, Germany: Institute of Forest Policy and Nature Conservation, University of Gottingen; Cuvillier Verlag.

Otsuka K, Suyanto, Sonobe T, Tomich TP. 2001. Evolution of land tenure institutions and development of agroforestry: evidence from customary land areas of Sumatra. Agricultural Economics 25(2002): 85-101.

Pariyanto. 2008. Jalan menikung: proses multipihak dalam pengakuan hutan adat. In: Adnan H, Tadjudin D, Yuliani L, Komarudin H, Lopulalan D, Siagian Y, Munggoro D, eds. 2008. Belajar Dari Bungo: Mengelola Sumberdaya Alam di Era Desentralisasi. Bogor, Indonesia: Center for International Forestry Research.

Pekelharing NR. 1925. De bevolkingsrubbercultuur in Nederlands Indie: 1. Djambi. Batavia, Nederlands-Indië: Departement van Landbouw, Nijv. en Handel.

Permatasari E. 2006. Lubuk Larangan dan perempuan. In: Yuliani L, Tadjudin D, Indriatmoko Y, Munggoro D, Gaban F, Maulana F, Adnan H, eds. 2006. Kehutanan Multipihak: Langkah Menuju Perubahan. Bogor, Indonesia: Center for International Forestry Research.

Permatasari E. 2008. Mereka bisa berubah. In: Adnan H, Tadjudin D, Yuliani L, Komarudin H, Lopulalan D, Siagian Y, Munggoro D, eds. 2008. Belajar Dari Bungo: Mengelola 
Sumberdaya Alam di Era Desentralisasi. Bogor, Indonesia: Center for International Forestry Research.

[RUPES] Rewards for, Use of, and Shared Investment in Pro-Poor Environmental Services Project. 2010. Lubuk Beringin village forest: the first in Indonesia. Bogor, Indonesia: World Agroforestry Center (ICRAF) Southeast Asia Program; International Fund for Agricultural Development. Available from http://rupes.worldagroforestry.org.

Rodiah. 2008. Hasil hutan non kayu dan ekonomi masyarakat. In: Adnan H, Tadjudin D, Yuliani L, Komarudin H, Lopulalan D, Siagian Y, Munggoro D, eds. 2008. Belajar Dari Bungo: Mengelola Sumberdaya Alam di Era Desentralisasi. Bogor, Indonesia: Center for International Forestry Research.

Samson AL. 1913. Een en ander over de bevolingsrubbercultuur in de afdeling Muara Boengo van de Residentie Djambi. Tijdschrift Binnenlands Bestuur 45: 292-314.

Sarma EH. 2006. Kelapa sawit: diminati, dienggani. In: Yuliani L, Tadjudin D, Indriatmoko Y, Munggoro D, Gaban F, Maulana F, Adnan H, eds. 2006. Kehutanan Multipihak: Langkah Menuju Perubahan. Bogor, Indonesia: Center for International Forestry Research.

Sarma EH, Rodiah, Adnan H. 2008. Mengatur diri sendiri melalui pengelolaan lubuk larang. In: Adnan H, Tadjudin D, Yuliani L, Komarudin H, Lopulalan D, Siagian Y, Munggoro D, eds. 2008. Belajar Dari Bungo: Mengelola Sumberdaya Alam di Era Desentralisasi. Bogor, Indonesia: Center for International Forestry Research.

Siagian Y, Neldysavrino. 2008. Aksi kolektif penguatan hak masyarakat atas lahan. In: Adnan H, Tadjudin D, Yuliani L, Komarudin H, Lopulalan D, Siagian Y, Munggoro D, eds. 2008. Belajar Dari Bungo: Mengelola Sumberdaya Alam di Era Desentralisasi. Bogor, Indonesia: Center for International Forestry Research.

Siagian Y, Neldysavrino. 2007. Collective action to secure land management rights for poor communities. CIFOR Governance Briefs 35. Bogor, Indonesia: Center for International Forestry Research.

Suherman K, Taher M. 2008. Potret perubahan tutupan hutan di Kabupaten Bungo 19902002. In: Adnan H, Tadjudin D, Yuliani L, Komarudin H, Lopulalan D, Siagian Y, Munggoro D, eds. 2008. Belajar Dari Bungo: Mengelola Sumberdaya Alam di Era Desentralisasi. Bogor, Indonesia: Center for International Forestry Research.

Suyanto. 1999. Evolution of indigenous land tenure institutions and tree resource management in Sumatra. Dissertation. Tokyo: Tokyo Metropolitan University.

Suyanto, Otsuka K. 2001. From deforestation to development of agroforest in customary land tenure areas of Sumatra. Asian Economic Journal 15: 1-17. 
Suyanto, Tomich TP, Otsuka K. 2001. Land tenure and farm management efficiency: the case of smallholder rubber production in customary land areas of Sumatra. Agroforestry Systems 50: 145-160.

Tata HL, van Noordwijk M, Werger M. 2008. Trees and regeneration in rubber agroforests and other forest-derived vegetation in Jambi (Sumatra, Indonesia). Journal of Forestry Research 5: 1-20.

Therville C. 2008. Rubber agroforests conversion in Bungo district (Jambi, Indonesia): perception survey and spatial analysis. Dissertation. Montpellier, France: University of Technology and Sciences/Montpellier II.

Therville C, Feintrenie L, Levang P. 2011. What do farmers think about forest conversion to plantations? Lessons learnt from Bungo district (Jambi, Indonesia). Forests, trees and livelihoods 20 (1). In press.

Syamsuddin, Neldysavrino, Komarudin H, Yuliana L, Siagian Y. 2007. Sudahkah aspirasi masyarakat terakomodir dan rencana pembangunan? Pelajaran dari aksi kolektif di Jambi. CIFOR Governance Briefs 34b. Bogor, Indonesia: Center for International Forestry Research.

Tomich TP, van Noordwijk M, Budidarseno S, Gillison A, Kusumanto T, Murdiyarso D, Stolle F, Fagi A. 1998. Alternatives to Slash-and-Burn in Indonesia. Summary report and synthesis of Phase II. Nairobi: ASB Partnership for the Tropical Forest Margins; World Agroforestry Centre (ICRAF). Available from http://www.asb.cgiar.org/regions/sea/indonesia/summary_report.asp.

Tomich TP, de Foresta H, Dennis R, Ketterings QM, Murdiyarso D, Palm CA, Stolle F, Suyanto, van Noordwijk M. 2002. Carbon offsets for conservation and development in Indonesia? American Journal of Alternative Agriculture 17: 125-137.

van der Meulen PJ. 1936. Memorie van Bestuurs overgave van het gewest Djambi. The Hague: Algemeen Rijksarchief.

van Noordwijk M, Tomich TP, Winahyu R, Murdiyarso D, Suyanto S, Partoharjono S, Fagi A. 1995. Alternatives to Slash and Burn: summary report of phase I. ASB Indonesia Report 4. Bogor, Indonesia: ASB Partnership for the Tropical Forest Margins, Indonesia; World Agroforestry Centre (ICRAF) Southeast Asia Program. Available from http://worldagroforestry.org/sea/publications?do=view_pub_detail\&pub_no=RP0001-04 . van Noordwijk M, Mulyoutami E, Sakuntaladewi N, Agus F. 2008. Swiddens in transition: shifted perceptions on shifting cultivators in Indonesia. Bogor, Indonesia: World Agroforestry Centre (ICRAF) Southeast Asia Program. 
White B. 2005. Nucleus and plasma: contract farming and the exercise of power in upland West Java. In: Li TM, ed. Transforming the Indonesian uplands: marginality, power and production. Amsterdam: Taylor and Francis e-Library. p. 229-256.

Yasmi Y. 2007. Institutionalization of conflict capability in the management of natural resources: theoretical perspectives and empirical experience in Indonesia. Wageningen, Netherlands: Wageningen University.

Yasmi Y. 2008. Peningkatan konflik dalam pengelolaan sumber daya hutan. In: Adnan H, Tadjudin D, Yuliani L, Komarudin H, Lopulalan D, Siagian Y, Munggoro D, eds. 2008. Belajar Dari Bungo: Mengelola Sumberdaya Alam di Era Desentralisasi. Bogor, Indonesia: Center for International Forestry Research.

Yuliani L, Tadjudin D, Indriatmoko Y, Munggoro DW, Gaban F, Maulana F, Adnan H, eds. 2006. Kehutanan multipihak: langkah menuju perubahan. Bogor, Indonesia: Center for International Forestry Research.

Zen Z, Barlow C, Gondowarsito R. 2006. Oil palm in Indonesian socio-economic improvement: a review of options. Canberra: Australian National University. 


\section{Annexes}

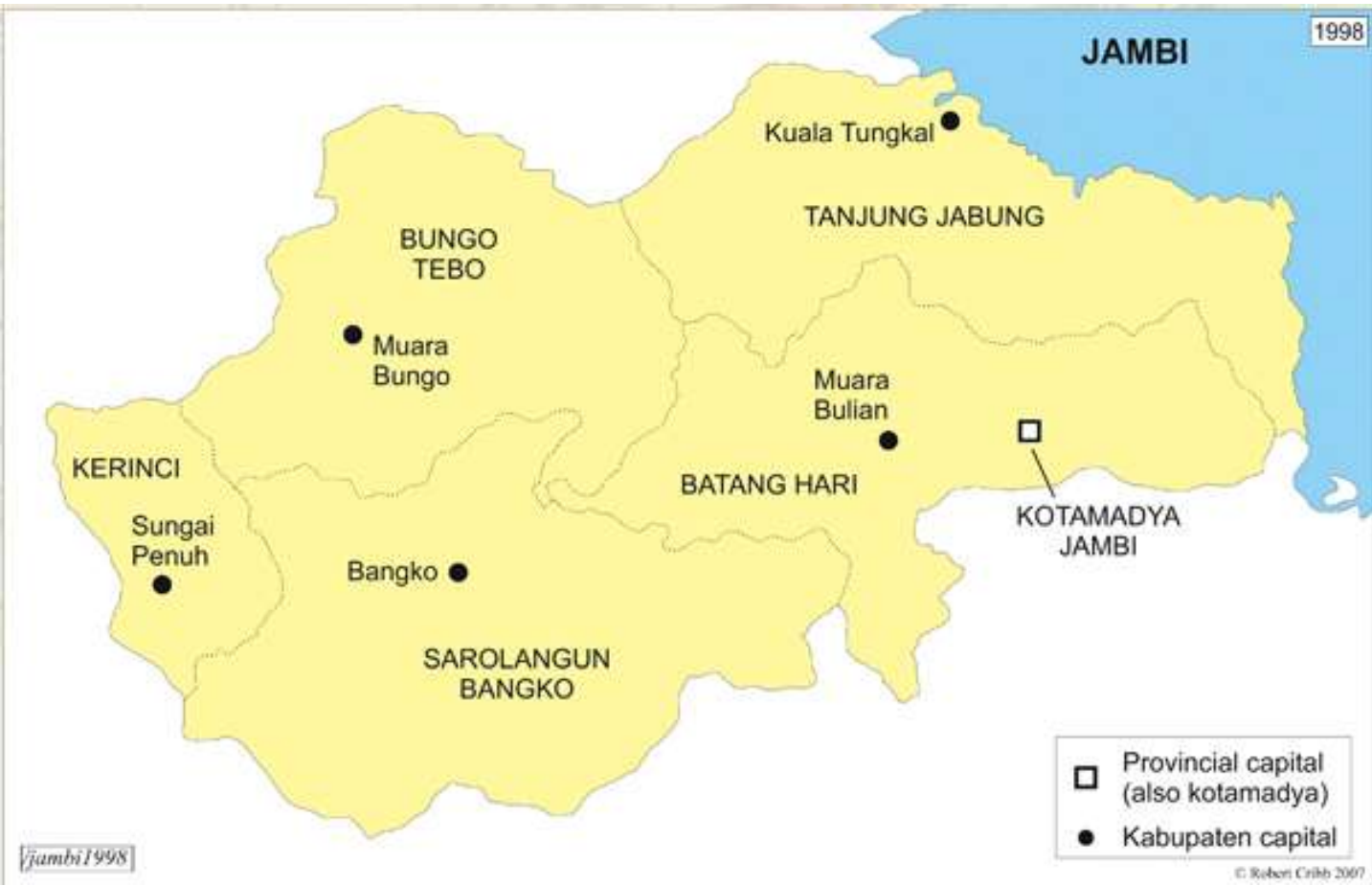

source: Digital Atlas of Indonesian History @ Robert Cribb 2010

Figure 1. Jambi administrative divisions, 1998

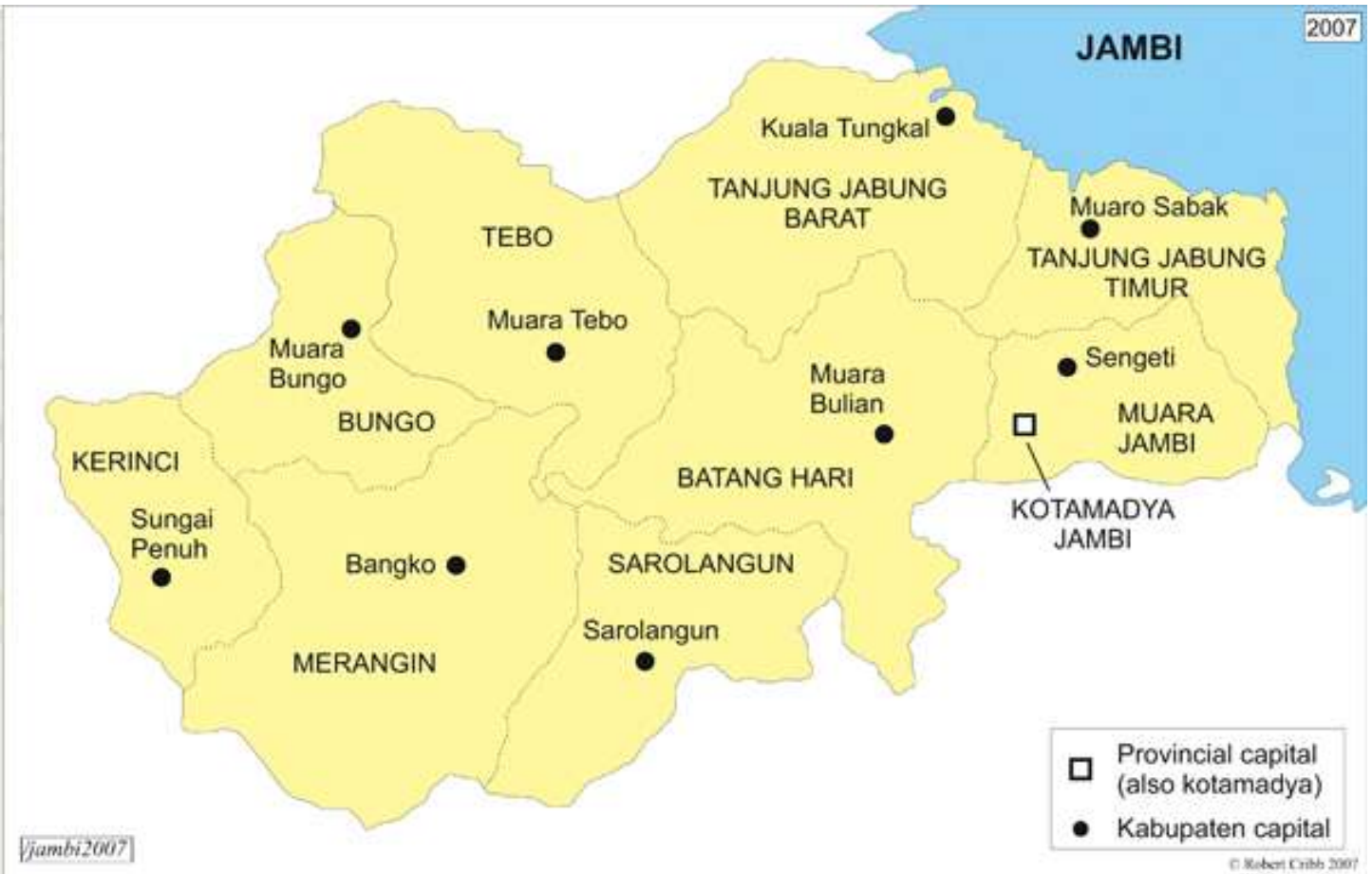

source: Digital Atlas of Indonesian History @ Robert Cribb 2010

Figure 2. Jambi administrative divisions, 2007 


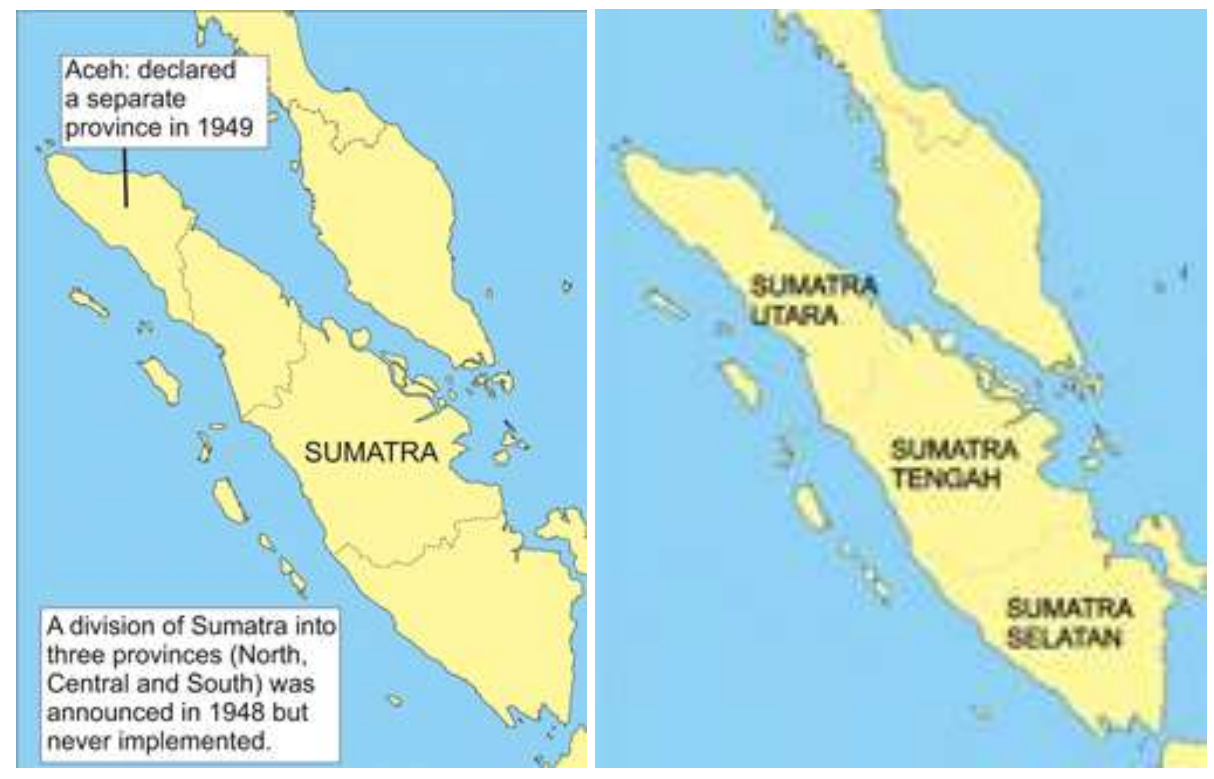

source: Digital Atlas of Indonesian History (C) Robert Cribb 2010

(A)

(B)

Figure 3. Republic of Indonesia provinces: (A) 1945-1950; (B) 1950-1955

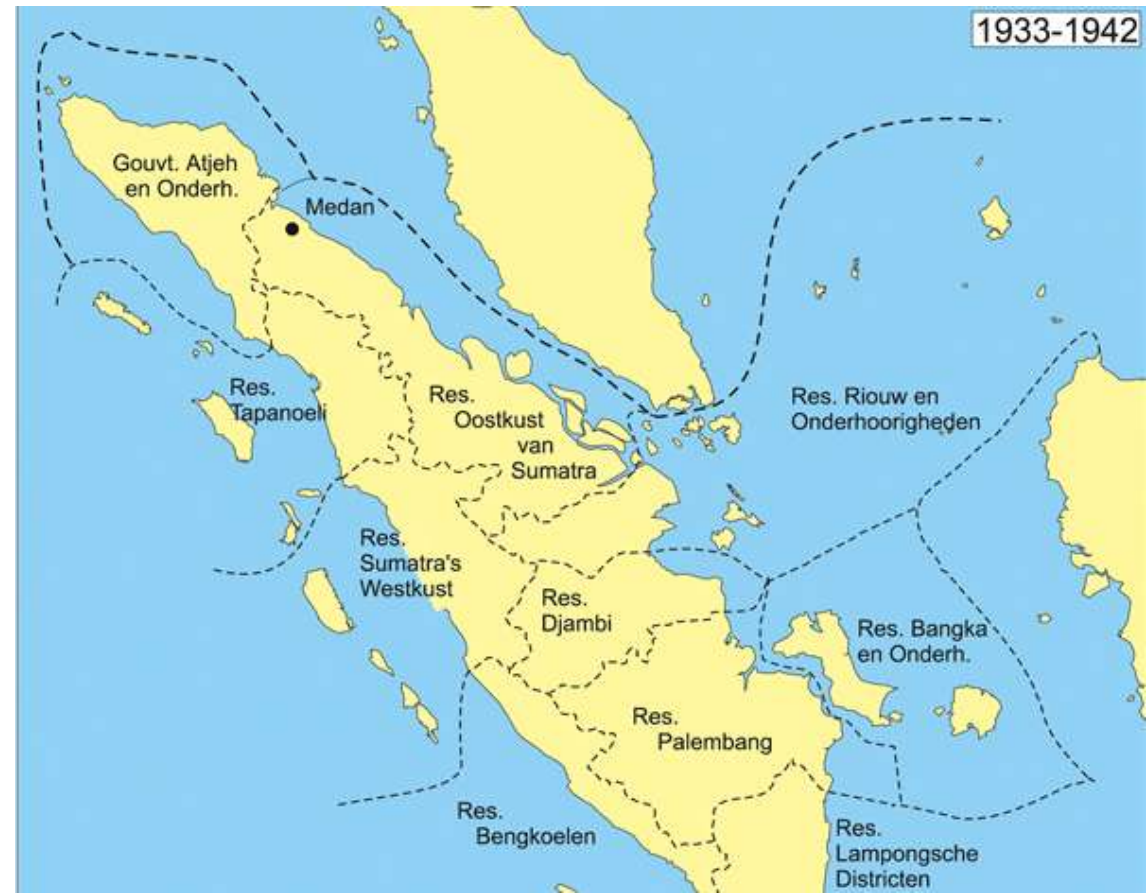

source: Digital Atlas of Indonesian History @ Robert Cribb 2010

Figure 4. Administrative divisions in Sumatra, 1933-1942 


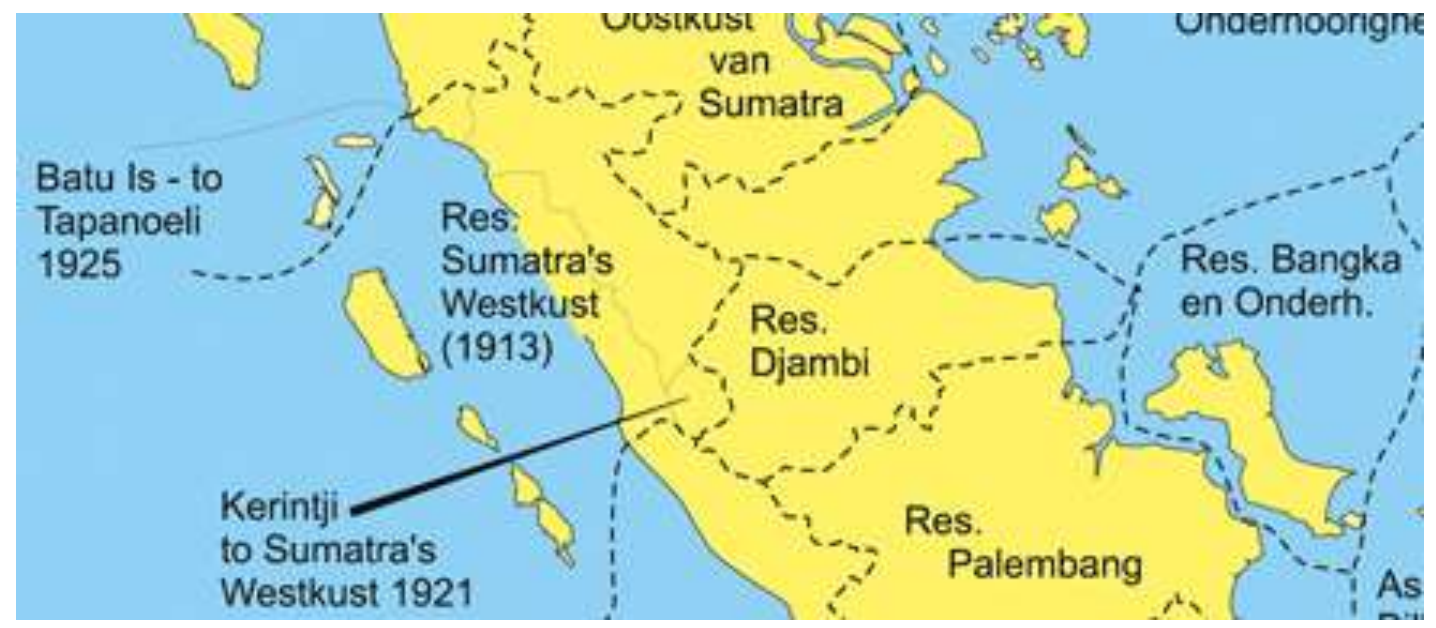

source: Digital Atlas of Indonesian History Robert Cribb 2010

Figure 5. Administrative divisions in Dutch Sumatra, 1906-1933

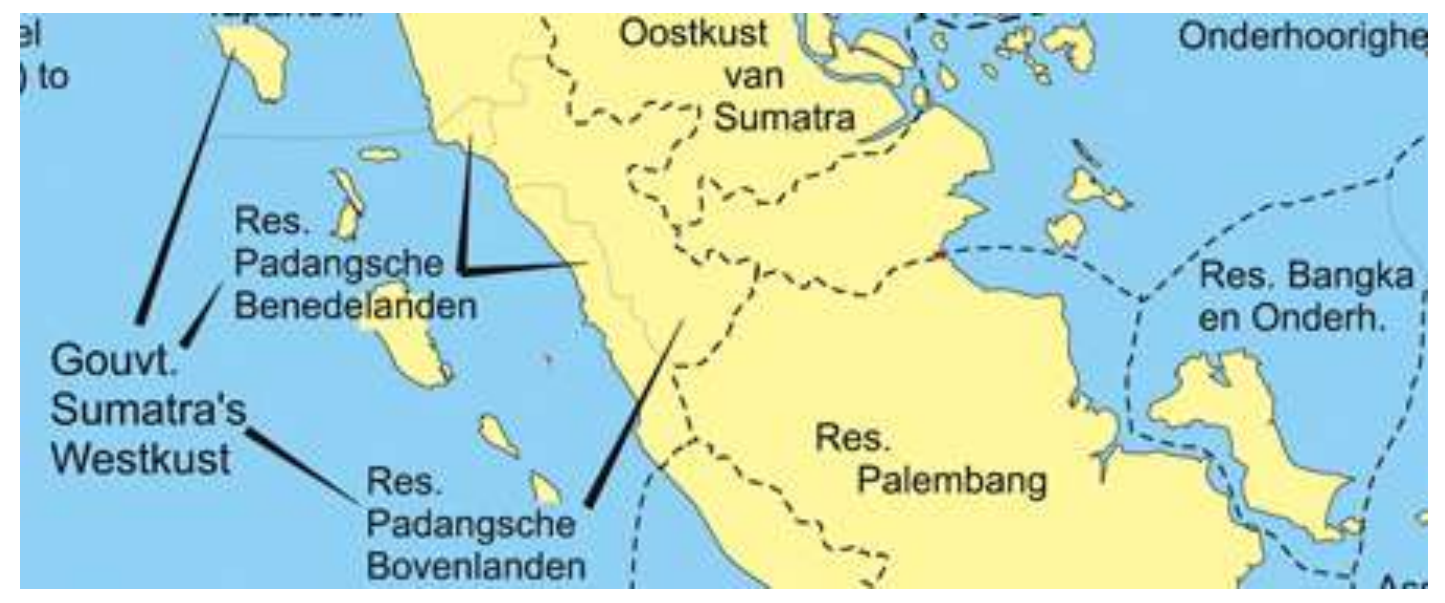

source: Digital Atlas of Indonesian History @ Robert Cribb 2010

Figure 6. Administrative divisions in Dutch Sumatra, 1873-1906

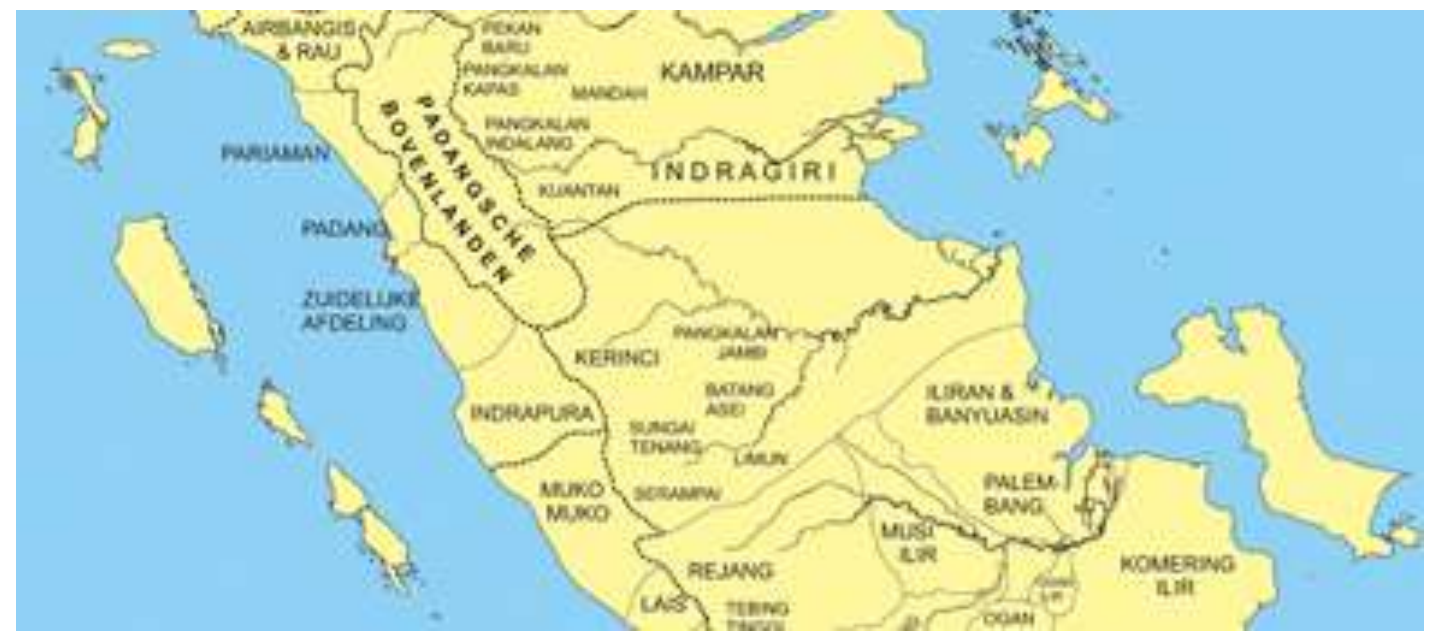

source: Digital Atlas of Indonesian History @ Robert Cribb 2010

Figure 7. Administrative divisions in Sumatra, 1877 


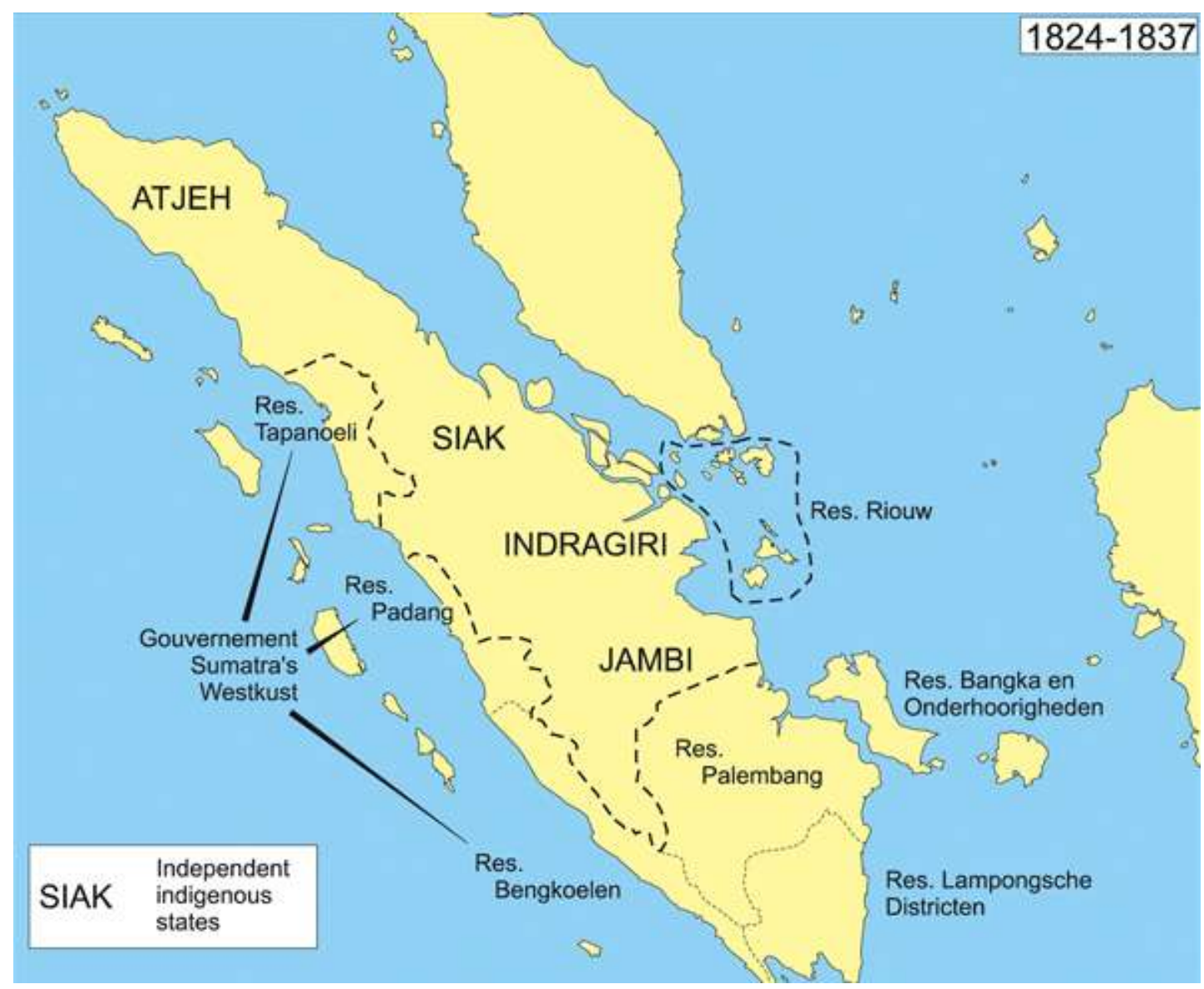

source: Digital Atlas of Indonesian History @ Robert Cribb 2010

Figure 8. Administrative division in Dutch Sumatra, 1824-1837 


\section{WORKING PAPERS IN THIS SERIES}

1. Agroforestry in the drylands of eastern Africa: a call to action.

2. Biodiversity conservation through agroforestry: managing tree species diversity within a network of community-based, nongovernmental, governmental and research organizations in western Kenya.

3. Invasion of prosopis juliflora and local livelihoods: case study from the Lake Baringo area of Kenya.

4. Leadership for change in farmers organizations: training report: Ridar Hotel, Kampala, 29th March to 2nd April 2005.

5. Domestication des espèces agroforestières au Sahel: situation actuelle et perspectives.

6. Relevé des données de biodiversité ligneuse: manuel du projet biodiversité des parcs agroforestiers au Sahel.

7. Improved land management in the Lake Victoria Basin: TransVic Project's draft report.

8. Livelihood capital, strategies and outcomes in the Taita hills of Kenya.

9. Les espèces ligneuses et leurs usages: les préférences des paysans dans le Cercle de Ségou, au Mali.

10. La biodiversité des espèces ligneuses: diversité arborée et unités de gestion du terroir dans le Cercle de Ségou, au Mali.

2006

11. Bird diversity and land use on the slopes of Mt. Kilimanjaro and the adjacent plains, Tanzania.

12. Water, women and local social organization in the Western Kenya Highlands.

13. Highlights of ongoing research of the World Agroforestry Centre in Indonesia.

14. Prospects of adoption of tree-based systems in a rural landscape and its likely impacts on carbon stocks and farmers' welfare: the FALLOW Model Application in Muara Sungkai, Lampung, Sumatra, in a 'Clean Development Mechanism' context.

15. Equipping integrated natural resource managers for healthy agroforestry landscapes.

16. Are they competing or compensating on farm? Status of indigenous and exotic tree species in a wide range of agro-ecological zones of Eastern and Central Kenya, surrounding Mt Kenya. 
17. Agro-biodiversity and CGIAR tree and forest science: approaches and examples from Sumatra.

18. Improving land management in eastern and southern Africa: a review of policies.

19. Farm and household economic study of Kecamatan Nanggung, Kabupaten Bogor, Indonesia: a socio-economic base line study of agroforestry innovations and livelihood enhancement.

20. Lessons from eastern Africa's unsustainable charcoal business.

21. Evolution of RELMA's approaches to land management: lessons from two decades of research and development in eastern and southern Africa.

22. Participatory watershed management: lessons from RELMA's work with farmers in eastern Africa.

23. Strengthening farmers' organizations: the experience of RELMA and ULAMP.

24. Promoting rainwater harvesting in eastern and southern Africa.

25. The role of livestock in integrated land management.

26. Status of carbon sequestration projects in Africa: potential benefits and challenges to scaling up.

27. Social and environmental trade-offs in tree species selection: a methodology for identifying niche incompatibilities in agroforestry [published as AHI Working Paper no. 9].

28. Managing trade-offs in agroforestry: from conflict to collaboration in natural resource management [published as AHI Working Paper no. 10].

29. Essai d'analyse de la prise en compte des systemes agroforestiers pa les legislations forestieres au Sahel: cas du Burkina Faso, du Mali, du Niger et du Senegal.

30. Etat de la recherche agroforestière au Rwanda etude bibliographique, période 19872003.

31. Science and technological innovations for improving soil fertility and management in Africa: a report for NEPAD's Science and Technology Forum.

32. Compensation and rewards for environmental services.

33. Latin American regional workshop on compensation ecosystem services report.

34 Asian regional workshop on compensation ecosystem services report.

35 African regional workshop on compensation ecosystem services report.

36 Exploring the inter-linkages among and between compensation and rewards for ecosystem services, CRES and human wellbeing. 
37 Criteria and indicators for environmental services compensation and reward mechanisms: realistic, voluntary, conditional and pro-poor.

38 The conditions for effective mechanisms of compensation and rewards for environmental services.

39 Organization and governance for fostering pro-poor compensation for environmental services.

40 How important are different types of compensation and reward mechanisms shaping poverty and ecosystem services across Africa, Asia and Latin America over the next two decades?

41. Risk mitigation in contract farming: the case of poultry, cotton, woodfuel and cereals in East Africa.

42. The RELMA savings and credit experiences: sowing the seed of sustainability.

43. Policy and institutional context for NRM in Kenya: challenges and opportunities for Landcare.

44. Nina-Nina Adoung Nasional di So! Field test of rapid land tenure assessment (RATA) in the Batang Toru Watershed, North Sumatra.

45. Is Hutan Tanaman Rakyat a new paradigm in community-based tree planting in Indonesia?

46. Socio-economic aspects of brackish water aquaculture (tambak) production in Nanggroe Aceh Darrusalam.

47. Farmer livelihoods in the humid forest and moist savannah zones of Cameroon.

48. Domestication, genre et vulnérabilité: participation des femmes, des jeunes et des catégories les plus pauvres à la domestication des arbres agroforestiers au Cameroun.

49. Land tenure and management in the districts around Mt Elgon: an assessment presented to the Mt Elgon ecosystem conservation programme.

50. The production and marketing of leaf meal from fodder shrubs in Tanga, Tanzania: a pro-poor enterprise for improving livestock productivity.

51. Buyers perspective on environmental services (ES) and commoditization as an approach to liberate ES markets in the Philippines.

52. Towards community-driven conservation in southwest China: reconciling state and local perceptions.

53. Biofuels in China: an analysis of the opportunities and challenges of jatropha curcas in Southwest China.

54. Jatropha curcas biodiesel production in Kenya: economics and potential value chain development for smallholder farmers 
55. Livelihoods and forest resources in Aceh and Nias for a sustainable forest resource management and economic progress.

56. Agroforestry on the interface of orangutan conservation and sustainable livelihoods in Batang Toru, North Sumatra.

\section{8}

57. Assessing the hydrological situation of Kapuas Hulu Basin, Kapuas Hulu Regency, West Kalimantan.

58. Assessing the hydrological situation of Talau Watershed, Belu Regency, East Nusa Tenggara.

59. Kajian kondisi hidrologis DAS Talau, Kabupaten Belu, Nusa Tenggara Timur.

60. Kajian kondisi hidrologis DAS Kapuas Hulu, Kabupaten Kapuas Hulu, Kalimantan Barat.

61. Lessons learned from community capacity-building activities to support agroforest as sustainable economic alternatives in Batang Toru orangutan habitat conservation program.

62. Mainstreaming climate change in the Philippines.

63. A conjoint analysis of farmer preferences for community forestry contracts in the Sumber Jaya Watershed, Indonesia.

64. The Highlands: a shower water tower in a changing climate and changing Asia.

65. Eco-certification: can it deliver conservation and development in the tropics?

66. Designing ecological and biodiversity sampling strategies: towards mainstreaming climate change in grassland management.

67. Participatory poverty and livelihood assessment report, Kalahan, Nueva Vizcaya, the Philippines.

68. An assessment of the potential for carbon finance in rangelands.

69. ECA trade-offs among ecosystem services in the Lake Victoria Basin.

70. Le business plan d'une petite entreprise rurale de production et de commercialisation des plants des arbres locaux : cas de quatre pépinières rurales au Cameroun.

71. Les unités de transformation des produits forestiers non ligneux alimentaires au Cameroun. Diagnostic technique et stratégie de développement Honoré Tabuna et Ingratia Kayitavu.

72. Les exportateurs camerounais de safou (Dacryodes edulis) sur le marché sous régional et international: profil, fonctionnement et stratégies de développement. 
73. Impact of the Southeast Asian Network for Agroforestry Education (SEANAFE) on agroforestry education capacity.

74. Setting landscape conservation targets and promoting them through compatible land use in the Philippines.

75. Review of methods for researching multistrata systems.

76. Study on economical viability of jatropha curcas L. plantations in Northern Tanzania: assessing farmers' prospects via cost-benefit analysis.

77. Cooperation in agroforestry between Ministry of Forestry of Indonesia and International Center for Research in Agroforestry.

78. China's bioenergy future: an analysis through the lens of Yunnan province.

79. Land tenure and agricultural productivity in Africa: a comparative analysis of the economics literature and recent policy strategies and reforms.

80. Boundary organizations, objects and agents: linking knowledge with action in agroforestry watersheds.

81. Reducing emissions from deforestation and forest degradation (REDD) in Indonesia: options and challenges for fair and efficient payment distribution mechanisms

82. Mainstreaming climate change into agricultural education: challenges and perspectives.

83. Challenging conventional mindsets and disconnects in conservation: the emerging role of eco-agriculture in Kenya's landscape mosaics.

84. Lesson learned RATA garut dan bengkunat: suatu upaya membedah kebijakan pelepasan kawasan hutan dan redistribusi tanah bekas kawasan hutan.

85. The emergence of forest land redistribution in Indonesia.

86. Commercial opportunities for fruit in Malawi.

87. Status of fruit production processing and marketing in Malawi.

88. Fraud in tree science.

89. Trees on farms: analysis of global extent and geographical patterns of agroforestry.

90. The springs of Nyando: water, social organization and livelihoods in Western Kenya.

91. Building capacity toward region-wide curriculum and teaching materials development in agroforestry education in Southeast Asia.

92. Overview of biomass energy technology in rural Yunnan.

93. A pro-growth pathway for reducing net GHG emissions in China. 
94. Analysis of local livelihoods from past to present in the central Kalimantan Ex-Mega Rice Project area.

95. Constraints and options to enhancing production of high quality feeds in dairy production in Kenya, Uganda and Rwanda.

96. Agroforestry education in the Philippines: status report from the Southeast Asian Network for Agroforestry Education (SEANAFE).

2010

97. Economic viability of jatropha curcas L. plantations in Northern Tanzania: assessing farmers' prospects via cost-benefit analysis.

98. Hot spot of emission and confusion: land tenure insecurity, contested policies and competing claims in the central Kalimantan Ex-Mega Rice Project area.

99. Agroforestry competences and human resources needs in the Philippines.

100. CES/COS/CIS paradigms for compensation and rewards to enhance environmental services.

101. Case study approach to region-wide curriculum and teaching materials development in agroforestry education in Southeast Asia.

102. Stewardship agreement to reduce emissions from deforestation and degradation (REDD): Lubuk Beringin's Hutan Desa as the first village forest in Indonesia.

103. Landscape dynamics over time and space from ecological perspective.

104. A performance-based reward for environmental services: an action research case of "RiverCare" in Way Besai sub-watersheds, Lampung, Indonesia.

105. Smallholder voluntary carbon scheme: an experience from Nagari Paningahan, West Sumatra, Indonesia.

106. Rapid Carbon Stock Appraisal (RACSA) in Kalahan, Nueva Vizcaya, Philippines.

107. Tree domestication by ICRAF and partners in the Peruvian Amazon: lessons learned and future prospects in the domain of the Amazon Initiative eco-regional program.

108. Memorias del Taller Nacional: "Iniciativas para Reducir la Deforestación en la region Andino - Amazónica", 09 de Abril del 2010. Proyecto REALU Peru.

109. Percepciones sobre la Equidad y Eficiencia en la cadena de valor de REDD en Perú: Reporte de Talleres en Ucayali, San Martín y Loreto, 2009. Proyecto REALU-Perú.

110. Reducción de emisiones de todos los Usos del Suelo. Reporte del Proyecto REALU Perú Fase 1. 
111. Programa Alternativas a la Tumba-y-Quema (ASB) en el Perú. Informe Resumen y Síntesis de la Fase II. 2da. versión revisada.

112. Estudio de las cadenas de abastecimiento de germoplasma forestal en la amazonía Boliviana.

113. Biodiesel in the Amazon.

114. Estudio de mercado de semillas forestales en la amazonía Colombiana.

115. Estudio de las cadenas de abastecimiento de germoplasma forestal en Ecuador.

116. How can systems thinking, social capital and social network analysis help programs achieve impact at scale?

117. Energy policies, forests and local communities in the Ucayali Region, Peruvian Amazon.

118. NTFPs as a source of livelihood diversification for local communities in the Batang Toru orangutan conservation program.

119. Studi Biodiversitas: Apakah agroforestry mampu mengkonservasi keanekaragaman hayati di DAS Konto?

120. Estimasi karbon tersimpan di lahan-lahan pertanian di DAS Konto, Jawa Timur.

121. Implementasi kaji cepat hidrologi (RHA) di Hulu DAS Brantas, Jawa Timur.

122. Kaji cepat hidrologi di daerah aliran sungai Krueng Peusangan, NAD, Sumatra.

123. A study of rapid hydrological appraisal in the Krueng Peusangan Watershed, NAD, Sumatra. 
The World Agroforestry Centre is an autonomous, non-profit research organization whose vision is a rural transformation in the developing world where smallholder households strategically increase their use of trees in agricultural landscapes to improve their food security, nutrition, income, health, shelter, energy resources and environmental sustainability. The Centre generates science-base knowledge about the diverse role that trees play in agricultural landscapes, and uses its research to advance policies and practices that benefit the poor and the environment.

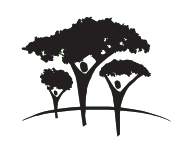

United Nations Avenue, Gigiri - PO Box 30677 - 00100 Nairobi, Kenya Tel: +254 207224000 or via USA +1 6508336645 Fax: +254207224001 or via USA +16508336646 Southeast Asia Regional Programme - Sindang Barang, Bogor 16680 PO Box161 Bogor 16001, Indonesia Tel: +62 251625415 - Fax: +62 251625416 www.worldagroforestry.org 